\title{
Looking at the bigger picture: A semiotic analysis on online news photographs
}

\author{
Moldez, Cheene $\measuredangle$ \\ Department of Education, Davao de Oro Division, Philippines (cheene.moldez@deped.gov.ph) \\ Gomez, Dan \\ University of Mindanao,Tagum, Philippines (dangomez031986@gmail.com)
}

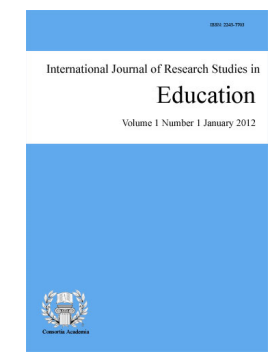

ISSN: 2243-7703 Online ISSN: 2243-7711

Received: 12 January 2022

\section{Abstract}

This study aimed to establish that online news photographs were dependent on language, using visual literacy. Semiotic analysis was utilized to determine the semiotic features present on the fifteen selected online news photographs. Also, a phenomenological approach was employed to highlight the information gathered on how students' understanding of online news photographs affects their personal viewpoints regarding issues in society and how semiotic features of online news photographs aid on visual literacy of students. The participants of the study were the fourteen (14) Grade 12 high school students in Maco North District, Division of Davao de Oro. There were seven participants for the in-depth interview (IDI) and seven participants for focus group discussion (FGD). This study obtained significant information that helped derive the semiotic features of photos based on their signifier, signified, denotative meaning, connotative meaning, and myth. Moreover, the study aided the understanding of students' viewpoints on issues in our society such as personal concerns, public awareness, clarity of message, stewards of the importance of news, sociological imagination, and civic action. Finally, participants shared how semiotic features aid their visual literacy, such as offering visual metalanguage, expressing emotions, and conveying messages.

Keywords: MAEd-Teaching English, semiotics, online news photographs, visual literacy, Philippines 


\section{Looking at the bigger picture: A semiotic analysis on online news photographs}

\section{Introduction}

News reflects the reality in our society. With all the issues our country faces right now, we need more information from online sources because they are one of the fastest and most convenient ways to get the latest information. Newman (2020) reported a dramatic increase in news consumption due to the coronavirus crisis, especially online, in all countries. Honing one's ability to evaluate, interpret and compose clear information from this online news is deemed necessary. Along this line, photography is an essential vehicle for reporting news. News photographs added significantly to the impact of words in print media. With all the pressing issues in the Philippines, photos play a vital role in supplementing the writer's message to convey to the audience. Thus, an added meaningful communication will be established by using not only words but also photos. The articles from the internet are being supplemented with photographs to intensify and further arouse the viewers' and readers' feelings towards the issue at hand (Lovelace, 2010).

News photographs are taken with a deliberate intention, that is, to send a message or story to the mind of the audience. Josephson, Kelly, and Smith (2020) stated that no other visual medium is at once so incisive and so immediate as a photograph where it confronts viewers on the various concerns and issues in need of awareness and action. Particularly, high school students must have the requisites in evaluating photos found in online news websites to further enhance their critical thinking skills as a member of the society. Nevertheless, an alarming result from the survey data of Brumberger (2011) revealed that twenty-first-century learners are not particularly proficient at producing and interpreting visual communication like films and images. Though these learners are still digital natives, they need to reach a significant degree of visual literacy. Even when constantly exposed to new technologies, enhancing skills in several areas, including those related to technology and visual communication, is still necessary.

Further, it was discovered by Romero and Bobkina (2021) that students lack preparation in visual communication given the context that they are 21 st-century students who need to be critical visual readers in this competitive world of visual communication. An English as a Second Language (ESL) classroom needs to emphasize the development of student's critical thinking and visual literacy. Teachers are the primary designer of learning experiences in the classroom and have a significant role in enhancing these necessary skills. Twenty-first-century learners are native image-viewers, and they will not be called image-readers without instruction and training on how to critically "read" images (Tester, 2017). Therefore, English teachers must include in their instruction not only the students' reading and writing skills but also verbal and nonverbal language. Teachers have a vital role in student's progress in their journey towards being critical visual readers. However, in the Philippines, Gabinete (2017) revealed that teachers were not formally trained in processing visual materials even with the use of technology as learning materials inside the classroom, and secondly, as a convenient replacement for a traditional text. This shows that enhancing the awareness of the importance of visual literacy is not merely for students but also for teachers.

In this study, I have taken into consideration the importance of developing students' visual literacy. According to Bradford (2011), 65\% of the population are visual learners. This data transpired an idea for me in addressing their learning visually. In this modern era, students learn or interested to learn through colorful pictures and interactive videos. However, even though students can be called "digital natives," it does not take away the idea that they still lack comprehension and critical analysis on different learning media like photos and videos presented to them, especially in high school. Students' lack of visual literacy will lead to poor comprehension. At present, I, as an English teacher, can relate to this problem in my English classroom wherein students cannot accurately describe a photo presented to them more so on its intended meaning. This is due to their lack of critical thinking skills, especially visually, affecting their comprehension. I am enthusiastic about 
conducting this study using semiotic analysis to extract students' understanding of photos and drawing reflections out of them.

I have not come across a study that is similar to the study currently taking; therefore, this research sought to fill this gap. This was done by probing into the semiotic features of online news photographs, sharing students' views, and understanding the given photos, which aids them in developing visual literacy. Since critical thinking is an essential factor in the learning process, I am inclined to conduct this kind of research. With all the issues and concerns presented, I am urged to study online news photographs' semiotic features to understand their meanings better and know what reflection can be drawn. I have a compelling desire to conduct this study to analyze its semiotic construction and gather systematic interpretations that lead to a better understanding of students' various viewpoints in society and how these semiotic features will aid the students' visual literacy.

\subsection{Purpose of the Study}

The purpose of this study is to identify the level of meanings of the online news photographs through semiotic analysis, which serves as significant signs in understanding photograph's meanings relating to social concerns. Also, this study aims to know how the semiotic features of news photographs found in various online news websites aids in the visual literacy of fourteen (14) Grade 12 senior high school HUMSS students at a secondary school in Davao de Oro. Further, through the deeper understanding of these photos through semiotic analysis, I could establish that images like online news photographs are interdependent on language using visual literacy.

This study is conceived to give a qualitative and interpretative semiotic analysis of online news photographs to create meanings and understand that communication is done not only through text and words but also through symbols, images, and photos. Thus, it aims to conduct a study concerning an in-depth analysis of online news photographs, inquiry of students' perception and understanding of the given photos, and how do this creation of meaning help in forming their own viewpoints concerning current issues in the Philippine context as well as in the development of their visual literacy. Visual literacy is an ability or skill on which an individual can make meaning of, understand, and comprehend images and other forms of multimedia. In this case, I try to seek students' understanding of news photographs through their interpretations, sound reflections, and implications regarding students' visual literacy through the said photos.

This study would try to examine how students interpret and evaluate news photos. High school students' daily activities involve looking and scrolling through their phones. Often, news articles pop out of their feeds. Most likely, students will read the headline and take a glimpse of the picture that comes with it. Therefore, this study would like to discover students' points of view, opinions, and understanding based on this daily activity. Specifically, HUMSS students need to be exposed to the societal issues reflected on the news photographs, enabling them to be aware of the current situation in society today and make a possible progressive change in the future.

The results give future directions for English teachers on how to facilitate learning inside the classroom, given that we are now in a much more technology-driven world, and learners are visual learners than ever. Through the study's results, teachers can have the knowledge and elicit strategies deemed necessary for the student's comprehension. Also, the four macro skills which are reading, writing, listening, and speaking have been repeatedly and thoroughly researched, and I believe that it is the right time also to explore the fifth macro skill, which is viewing. Thus, this study focuses on gaining additional body knowledge in research concerning semiotic analysis and students' critical analysis.

\subsection{Research Questions}

This research aims to determine the semiotic analysis on online news photographs and to explore the visual literacy of senior high school students. In connection to this, the following questions were formulated: 
$>\quad$ What are the semiotic features present in online news photographs?

$>\quad$ How does students' understanding of online news photographs affect their personal viewpoints regarding issues in society?

$>$ How do the semiotic features of online news photographs aid in the visual literacy of students?

\subsection{Theoretical Lens}

This study is gleaned from the Semiotics Theory of Ferdinand de Saussure (1959), which states that a person lives in a world shaped by decoded signs found in images, actions, words, and more that he or she has encountered. The purpose of semiotics is to become aware of the construction of reality created by those signs. The signifier is the material aspect of the sign, while the signified is considered the mental concept. In this study, the signifier refers to the online news photographs, while the signified refers to the mental concept formed upon seeing the signifier. Specifically, in this study, it is relevant to also use Roland Barthes' theory of semiotics (1977) for it can answer the problem formulation contained in this study which primarily focused on semiotic features of online news photographs. This theory makes a systematic model in analyzing the meaning of signs. It mainly probes into the photo (signifier) and looks for messages to be conveyed through signified.

In connection to this, the theory of Order of Signification proposed by Roland Barthes (1977) is used for analysis. This analysis is divided into three concepts: denotative, connotative, and myth. According to Chandler (2017), denotation can be described as the literal, explicit, and obvious meaning of a sign. Next, the connotation refers to the understood emotional and socio-cultural meaning of a particular sign. Myths signify the naturalized meaning of a sign in a certain culture. It is how a culture indicates and grants meaning to the signs around us. It is a social product in which culture explains or understands some aspect of reality or natural phenomena (Barthes, 1977).

In context, the theory of Order of Signification probes into the denotative, connotative, and myth of the chosen online news photographs. The denotative meaning of news photos determines the visual elements like people, environment, and objects present in a photo. The connotative meaning will look into the profound meaning of these photos beyond what the obvious signs in a photo suggest. Lastly, myth indicates the general meaning of the photos concerning the Philippine culture and setting. Moreover, the social semiotics of Halliday (1978) is also an appropriate theoretical paradigm where this study is anchored to. Since the study revolved around understanding meaning in a particular society, this theory focuses on creating social meaning (within texts and society). This theory links social semiotic "signs" as represented in photos to contexts or socio-cultural environments and argues that all "resources" represent an ideology. Specifically, through this theoretical paradigm, I deconstruct the signs (photos) found within the photo under analysis, enabling me to make connections and interpretations to the environments/contexts in which each photo was produced.

The three major theories presented in the study are chosen for their relevance with the study of semiotics. These theories verify that study of signs is necessary to make meaning out of codes like symbols and images. These signs are not a set of nonsense codes with meaningless interpretations but something that bears a significant meaning to create meaningful interpretations of the world we live in today.

\subsection{Significance of the Study}

This qualitative study aims to add the usefulness of educating senior high school students in visual literacy. Through the findings and relevant data that this study provides, I can obtain useful information to establish that photos, which is just one of the many signs around us, are essential elements in the whole communication process, especially on critical thinking of our young learners who are considered to be the hope of our nation. With all the news photographs circulating online, it is not enough to glance at a photo and create various reactions to the situation. The semiotic analysis gives us a more profound understanding of issues in our society

4 Consortia Academia Publishing (A partner of Network of Professional Researchers and Educators) 
and helps the learners to create and inculcate in their young minds a sound reflection that will lead to a solid plan of action later.

More importantly, the knowledge gained from this study helps teachers to be reminded of using relevant social content in their classes and giving students the chance to pour out their deepest and sincerest ideas out of a carefully selected photo under analysis. For the students, by analyzing photographs related to current events, students will not only improve their visual literacy but will also develop desired values such as nationalism, justice, moral uprightness, inclusiveness, understanding, and compassion, which is the aim of the Bureau of Learning Resources. Therefore, this study is helpful in attaining the quality education goal of the Department of Education. Moreover, a study is made not just to collect information and facts. The greatest cause it is made is to address and remedy issues occurring in a community or society in general. The result of this study is helpful and significant to all the people interested in using semiotic analysis as a method to interpret photos and realize that there is a meaningful message behind every photograph. I hope this study is helpful for Graduate School students who would like to enrich their understanding of semiotic on online news photographs especially guided by the presented theories.

Lastly, it cannot be denied how social media and online platforms take over our need for daily news and updates happening in our society. Most of the time, online news is paired with photos to intensify the delivery of the information. Analyzing the signs, denotation, connotation, and myths of these online news photographs could give some of the advantages for the reader interested in the semiotic field for analyzing the deeper meanings and interpretations that manifest in various ways. Semiotic can be applied in analyzing many signs, photographs, advertisements, linguistic codes, pop culture codes, and many others.

\section{Literature review}

\subsection{Semiotic Analysis}

Semiotic analysis is the process of deepened analysis of signs within a context that can draw out meaning generated based on sound discourse and fair examination. It is an analysis of codes and symbols utilized for communicative purposes to produce meaning. But the true and accurate meaning can only be produced based on a thorough and fair examination (Jenkins, 2011). When we go back to the infancy years of semiotic analysis, we provided rigorous work about it. In his quest, he made a clearer description of the three Saussurean terms: the signified, the signifier, and the sign. He defined signified as the concept, the signifier as the mental picture, and the sign as a concrete substance marked by the relationship between the concept (signified) and the image (signifier). Additionally, he stated that myths could consist of written discourse and representations such as cinema, reporting, photography, and many more. He further expressed that those mythologies subtly distort reality through semiotics, often described as the "science of forms" (Barthes, 1977).

In the hopes of expanding this discipline, the semiotic analysis sought to involve its scope into finding out what this kind of study can contribute to the betterment of society. Social Semiotics emphasized the use of semiotic systems in social discourses. They stressed that for the message producers to function, they must depend on their recipients, and that process will draw out the social power of the message in society. An example of this is feminist activists changes the sexist advertising billboard and spray paint it to a feminist message (Hodge \& Kress, 1988). In support of these assertions, society in the contemporary era is described as "eye-centered" as the visual setting was given great importance and its effect on the guidance it generates in social discourse. This time around, as people became more and more visual learners, signs also become a subject of interest for researchers. They have recognized the importance of semiotic analysis in the communicative process (Mirzoeff, 1998).

Furthermore, signs are powerful in communication. For example, visuals in a demonstration and protest can provide powerful meanings for mass mobilization. The way of thinking and believing influences the way we 
perceive things. The innate nature of images brings about general language, which can draw protest messages and generate shocking emotions (Berger, 1978). Aside from protests and demonstrations, visuals are also important in the field of marketing. Logos, taglines, and other communication elements help construct the face of a company which will be vital in maintaining communication towards the customers. However, the challenge for a marketing professional is to overcome the difference between the kind of face the company projects and the face perceived by its customers. Therefore, a marketing professional should understand very well how signs communicate meanings (Chattopadhyay, 2017).

Specifically, semiotic analysis of media text like in newspapers is a detailed examination of symbols in media texts and the language of signs. As media agencies often provide simple solutions for complex problems, identification analysis identifies and recognizes hidden meanings in media texts. The media educators are encouraged to use educational games with functional content to understand how ideas are hidden behind media texts. He further stated that the use of media text analysis could effectively enhance critical thinking as well as media competence among students (Fedorov, 2015). Today, people must realize the poignant influence semiotics has brought to the design industry today for the businessman and consumers. Signs and symbols are everywhere, allowing the consumer to freely make sense and generate meaning (Aljoundi, 2013).

Moreover, photographic semiotics is the study of making meaning between a photographic image and its audience. Hence, to realize the photographer's intentions, the audience must give importance to understanding the meaning behind the photos. The semiotic analysis allows the audience to gain more profound realizations and meaningful reflections of this matter (Leon, 2017). However, there is no superior approach in the field of semiotics. The superiority is determined by the consistency of the method used rather than by its inherent methodological differences. Regardless of the kind of methodological approach that is applied, it will always include additional elements. These elements embody an open structure that is perceived and interpreted in various ways (Batu, 2012).

\subsection{Denotation}

Denotation refers to the literal meaning of a term or object. A visual description of a burger on how it weighs and what sauces come with it or the physical description of a Barbie doll based on its vital statistics and when it was first marketed are all denotative meanings. Therefore, denotations tell us about the apparent meaning of an object or term (SAGE Publications, 2020). This is supported by definition stating that denotation is often termed "reading the lines" or a word's literal or dictionary meaning. People use language to represent ideas, feelings, concepts, or objects using signs and symbols. Denotation and connotation are common approaches in undermining messages of an unfamiliar term or sign (Rao, 2017).

In the field of semiotics, denotation refers to an interpretation of a message to its literal meaning of signs and symbols, often by something obvious, observable, and visible to the eyes. If we describe its denotative meaning in a picture, we refer to something visible to the eyes or something noticeable (Limesa, 2018). In news media, which is commonly stated as journalism, photos are frequently associated with current events. These pictures provide a summary and additional information to the news story. When people view these pictures, they create a denotative message in their heads, which is thought to be the first signaling order to explain the connection between the components in the sign and the referent in the external world (Arifin, 2019).

The denotative level description of a certain news photo refers to the photographic elements like how people look and what they are doing. This level of interpretation provides a simple description of a photo with speculative verbs and descriptive adjectives or adverbs. The use of speculative verbs in describing photos allows for the heterogeneity of meanings to be practiced. So, a person's descriptions may not be incongruent with someone else's descriptions (Lacković, 2020). In comparison, denotation is a precise translation of a sign or message with no added values or meanings, while connotation is a suggestive kind of translation where the messages and signs were added with additional value. The denotative meaning of pictures and photographs

6 Consortia Academia Publishing (A partner of Network of Professional Researchers and Educators) 
comes with looking into the picture as a whole, and its connotative meaning will be derived by adding value to the picture (Saifuddin, 2018). It is important to remember that most semioticians argue that there is no strict division between denotative and connotative meaning because meaning is always accompanied by value judgment. Thus, no sign is purely denotative that lacks connotation. Signs are open to any kind of interpretation, whether translated as a "digital code" (denotation) or as "analogue code" (connotation) (Chandler, 2017).

\subsection{Connotation}

Connotation refers to the association or idea suggested by a word or phrase. Also, it is an implication of a thing or idea. These are the ideas or qualities that make you think of something else beyond what perceives the eyes. Thus, the connotation is the meaning formulated subjectively by an individual. Every one of us has different connotations on a single object or idea (Collins, 2020). Culture influences us on the way we think and perceives a thing. Hence, our connotations are deeply influenced by culture. One symbol is not only defined by one meaning. To determine a symbol's connotative meaning, one must be open to any interpretation (Underwood, 2003). In writing, determining the connotative meaning of texts will take into consideration the coherence and identity of the text. With this, the issue of a closed and open system in constructing meaning is raised. In a closed system, one must approach the text by determining what the author wants to convey. In an open system, aside from the author's purpose, one must also consider his or her opinion. Thus, it can be argued that there is no correct way of meaning construction as it is open to any interpretation (Huhtamo, 2003).

In the field of economics, products are inherently given with cultural, social, and ideological features through connotations. The kind of commodities people prefers to use reflect social differences. Connotations are not purely defined by personal meanings but also through the type of codes the translator has in his or her environment. Culture has a significant influence in providing codes to create frameworks for connotations recognized within a specific culture (Yan \& Ming, 2015). On the other hand, in semiotics, connotation refers to the interrelated connections between personal and socio-cultural implications of symbols. These implications are influenced by the person's class, gender, age, ethnicity, etc. Connotations provide a more open interpretation of signs rather than in its denotative meanings (Mambrol, 2016). Journalistic photographs are loaded with meanings and emotions. They require profound interpretation and consider to be more credible than any kind of image. Thus, this kind of photograph is not just simple news that is visually communicated but a visual interpretation of reality to be analyzed in a more advanced (connotative) manner. Connotation, therefore, is intended to use as a tool to interpret meaning and purpose (Kedra, 2016).

Also, the subjective side of photography is the connoted message we add to the photographs. It depends on how a viewer builds upon the information he perceived. If the denoted message focuses on the photos' content, the connoted message is the individual and holistic interpretation from the photos presented (Rice, 2016). Additionally, people vary in their opinions as well as in getting the connotative meanings of signs. To use connotations in constructing meanings, one must use context rooted in a person's experiences, ideologies, schemas, and mental models. Therefore, people would never have the same connotations when interpreting the same signs (Bradley, 2016). Connection is important for it generates culturally significant interpretations of mass media texts and genres. Connotations, which is the second level of meaning, require some deeper probe into the culture of a particular audience. Through this, a much more meaningful interpretation can be realized (Arackal, 2015). An analysis of signs includes an interpretation of the interrelated connections of its denotative and connotative meanings. Connotations must be carefully interwoven in the whole advertisement to avoid ambiguous meanings. The connotative meaning of an advertisement represents the overall message the ad wants to convey. This can be done by looking into the image created by the ad producers, like the photographed model. Naturally, the model connotes feminine beauty, which makes an ad effective (Džanić, 2013).

\subsection{Myth}

Myths are a set of accepted beliefs or ideas that could serve as a foundation for a lower-level denotation 
system or connotation. Myths have an ideological function that is widely accepted by society, making them seem natural and unchangeable. A myth may be large-scale and long-lasting or may die out or be short-lived (Mingers \& Willcock, 2017). Politically, signs in the environments have myths that hide political meaning, which is often seen as its natural meaning. In that sense, analyzing political or ideological codes and reading signs are two identical things. Further, the semiological reading approach was used in analyzing mythicized discourses within the educational process. Thus, semiological reading interprets an object or a sign not just with its primary meaning but also with its cultural code or metaphorical meanings (Kukurt, 2016).

Further, myth analysis is an interpretation of the relationship of the sign system that creates meaning based on cultural assumptions. The process involves awareness and recognition of the hidden meaning behind the sign system. However, myth carries assumptions that appear not only natural but are historical. Myth, the third level of signification, gives an understanding of a sign far beyond what denotation and connotation can provide (Gaines, 2002). Myth can be termed as the advanced interpretation of denotation and connotation adapted within society's condition and culture. When a symbol has a denotative meaning, then this denotation will be developed into a connotation which will then be classified as myth. For instance, a lush bamboo tree caused connotation of "spooky and sacred" because it is regarded as the dwelling place of the spirits. This "spooky and sacred" connotation then becomes a common belief attached to the bamboo tree symbol. In this level, "spooky and sacred bamboo tree" is regarded as a myth finally (Rifa, 2018).

For instance, news photos of Ramadan generate a social construction of Muslim identity in Indonesia. A positive message was conveyed by portraying the activities and routines performed by Muslims. Through the construction of meaning in the photos, people understand the daily life culture of the people and how precious this event is to them. The socio-cultural values and traditions are strengthened and maintained through the myth emanated by these news photographs (Harahap, Kholil, \& Zulkarnain, 2020). Culturally speaking, myth is considered a metaphor that relates signs to the norms, historical events, attitudes, and cultural values of a region. It specifies implications based on cultural beliefs and values. In referring to the news photos, the dominating ideology influences the narrative of signs in society (Sagimin \& Sari, 2020). Myth is widely accepted by society and represents a chain of events on which the interpreter often only relates to a single sign. Most importantly, myth is intentionally created by groups of people to convey messages that preserve existing power structures (Stedman, 2019).

\subsection{Understanding News Photography}

News photography is the photography of newsworthy events. News photographs are visual text that bears more impact than written text. Inevitably, viewers notice images first, which makes it a powerful medium for information. Hence, observance of ethics in news photography is crucial to avoid serious violations. In present times, anybody can break the news if they are in a place where an interesting or important event is happening (Vujović \& Prelevic, 2014). Admittedly, newspapers and online articles will never fully achieve its purpose of informing the public without first catching their attention with photos. Consequently, they cited the importance of news pictures in newspapers. Mainly, pictures help to brighten the page because without images, it looks dull, and readers will not be bothered to read what is written. Often, without reading the full article, a picture can tell the news by itself. Other times, photos may go with the story news, and together they served their primary purpose of informing the latest information. Whatever the case, news pictures must always carry information leaving the viewers and readers knowing more than what they have just actually read on a black and white page (Ingram \& Henshall, 2019).

Various news industry has their own way of utilizing words and selecting photographs to abide with the rules and style for the company. Journalists and photojournalists have to abide by this set of styles compelling them to set aside their own preferences. Even though newspapers in the Philippines have a unique manner of portraying news both in print and digital, one thing that is common amongst them is the purpose of educating the readers on the current events that would affect the economy and society. No matter where the company they are

8 Consortia Academia Publishing (A partner of Network of Professional Researchers and Educators) 
working from, Journalists take the Philippine Journalists' Code of Ethics (Reyes et al., 2012). The experience of audiences is of great importance in news photography. In selecting worthy photos for viewing and printing, the perception of the audience is considered. But she admitted that there is a need for more research in this area given the ever-changing media content, visual language, and viewing practices of the audience. People can become passive consumers of news. The people remain to be manipulated, and they would not be able to detect media spin. Worse, few only would try to check the inaccuracies in a report, and if they knew, they would not be bothered to complain or express criticisms (Nilsson, 2017).

Additionally, since Filipinos are active users of digital and social media and we are considered the "Selfie Capital of the World" in 2014, our engagement on various issues like politics also rises. Many photos can be uploaded in real-time, and information can be regarded or disregarded as it is happening. But the downside to all of these is social media can disrepute the traditional media and has been used to disseminate fake news for political propaganda. These instances are the reasons why media literacy must be advocated by all Filipino netizens (Karunugan, 2019). At present times, we readily recognize the contribution of ordinary citizens in news photography. Citizen journalism has been normalized wherein ordinary citizens can break the news anywhere and anytime using their smartphones and share it across social networking sites. For instance, capturing the calamities through cellphones to produce amateur photographs and video footage were recognized in the field of professional news photographs (Allan, 2015).

Finally, as everybody acquires cellphones and can post photos on various online social media platforms, appreciation for photography is continually soaring high. Other boundaries are being crossed where visual artists exhibit photographic works, while photojournalists are also creating works of art. Indeed, visual images never fail to capture our attention and communicate its intent to the audience. Hence, photojournalism in the Philippines appeals not only on the news but could also be exhibited and shown to the general public as a form of art (Caruncho, 2020).

\subsection{Semiotic Analysis on Photographs}

Semiotic analysis aims to analyze the signs and codes and interpret it in relation to the society where it belongs. Photojournalists take into consideration the angle, subject, lighting, and other small elements to send a message to the audience. Like any other form of media, the Photograph is a very powerful tool in molding the minds of the audience. Photojournalists and media practitioners should always remember their responsibility to take pictures and create stories that report honestly, truthfully, and objectively (Morabe, 2014). The study on the semiotic analysis of photographic captions asserts that verbal signs in news photos hold importance in photojournalism. A picture may speak various possible meanings, and captions and cut lines are used to limit the polysemic nature of these images. Without the captions, a photo will not be contextualized, and it will be hard for the reader and viewer to discern its intended meaning. These captions can either limit the photo's denotative meaning or connotative meaning to narrow down every possible meaning unrelated to what it intends to communicate to the audience (Park, 2015).

Moreover, the visual-semiotic study suggested that photos can generate a humanistic portrayal. In their research, where four photographs were examined from a specific ethnic group (Rohingya), the shock effect manifested by their grim ordeal was highlighted. Their resilience and strength were also being acknowledged. Photography and the politics of viewing show the potential to get people to act and intervene against violent state policies on forced migration (Yeung \& Lenette, 2015). In relation to this, a study has stated that images hold power in moving the world. News photos invite readers to go beyond the visual illustration and read the text that this illustration is made to portray. Particularly, this statement is evident in a tragedy-themed news story. In fact, one of the findings from a study entitled "Albayanos" perception on the online media's graphic presentation of tragedies" asserted that images allow for a better understanding of the content of news stories, especially on disasters to human beings (Carullo et al., 2019). 
As visual communication assumes dominance, the image holds greater importance on the human consciousness than expressive words. A comparison was made between image and words stating that our world today will never be possible without image; even thinking is impossible without it. Thinking with images helps produce connotations. In the present day, the image produced has created the form of prescriptive, intensive signs and made these "signs" essential in our lives. Therefore, the photo enables the enormous role played by signs and symbols in controlling our daily lives (Fidouh, 2014). Further, images have transcended the monotony of words and can tell the same story, sometimes, better. The study, which investigated the semiotic and linguistic effects of road carnage visual images in print media, has become a new and effective mode of communication at an emotional level. Through this, the general public, particularly drivers, will understand the urgency of following driving rules and regulations. Thus, the effect of these images has helped the government in its campaign for protection against fatal road accidents (Mutangadura et al., 2019).

Another study reiterated the changes of the trend in news media, where it evolved from text-based reporting from the past to embracing multisemiotic interfaces today. Primarily, this change is brought about by technology where photos, videos, and other visually interesting elements are made available everywhere. Thus, semiotic analysis has been utilized to interpret these signs. In the context of photojournalism, it is both timely and relevant for readers to explore the importance and popularity of images in current journalism, both in print and digital news media (Caple, 2016). In addition, photographs are a great source of information because visual images are recalled more quickly and serve for a longer time than words. Images can "trigger" people's innate values, way of thinking, and feelings. These ideas can reflect how a photo can be interpreted. That is why semiotics can be a method to shape and analyze the meaning of photos. As a result, the theory of semiotics is useful for interpreting meanings in intercultural communication, especially in the online news photographs in the Philippines. The expression "a picture is worth a thousand words" helps explain the unique qualities of photography (Topbas, 2011). Aside from news, a semiotic analysis may also be applied in different fields of discipline. One of which is in fashion photography. Guided by Roland Barthes' theory of semiotics, the study has probed into the semiotic structure of photos and concluded that fashion speaks a distinct language, whether it is an individual's personal dress or a passing trend, which symbolizes the essence of its social context (Butler, 2015).

\subsection{Visual Literacy}

Visual literacy is described as the ability to read, write, and make visual images. It is a concept that requires people to define and redefine ideas as the world changes consistently. People use visual media as a linguistic tool to communicate, exchange ideas, and explore the world. Digital technology played a big role to be able to develop visual literacy (Harrison, 2020). Moreover, visual literacy is a group of vision competencies that requires viewing and integrating all other senses. The achievement of these competencies is integral to human learning. When visual literacy is highly developed, it enables a person to become a visually literate person able to discriminate and interpret visible objects, symbols, and signs in their environment (Debes \& Williams, 1978). In this era of education, viewing became an integral part of learning. Television, desktop computers, laptops, and smartphones have become the primary source of students' information, especially in today's society. Visual literacy was advocated and is widely used to enhance students' comprehension and improve their macro skills (Furigay, 2016).

Furthermore, visual literacy becomes an essential competency for twenty-first-century learners. It is the ability to provide meaning, utilize, and appreciate photos and videos for communication and learning, should be taught in school alongside critical reading and other literacies. Digital technology has advanced the growth of information and boosted the availability of digital photos and other nontextual formats. This digital transformation was accompanied by widespread information sources and the expanded importance of image as a mode of knowledge representation. This became a major factor in how students use information sources and make meaning in the world (Matusiak et al., 2019). An alarming study revealed a discrepancy between home visual literacy practices and school visual literacy teaching. The learners were able to develop communication skills through digital technology but displayed low reading culture. This finding suggests the need to inculcate to

10 Consortia Academia Publishing (A partner of Network of Professional Researchers and Educators) 
the learners the importance of reading which will help to enhance their overall critical thinking (Mnyanda, 2017).

Given the concern that needs to be addressed, educators should be aware of the new sources and materials to be used in teaching. As a result of the advancement of technology, new forms of visual and digital texts have emerged. An example of a visual text is a meme. Memes are engaging and effective tools for practicing visual literacy among students. It is appealing, and it targets the audience's attention. Memes could enhance students' macro skills as it triggers student's reading, writing, and viewing skills. On the basis that learners engage with memes, students must also appreciate the composition of the meme and recognize the purpose and relevance of the meme (Clayton, 2019). Photo elicitation provides a wide range of pedagogical values; it also allows visualization of students' everyday experiences, triggers emotion and extracts personal meaning, advocates real-life and active learning, activates critical consciousness, and improves students' visual literacy (Chai, 2019).

Literacy is important for us to understand and analyze how signs and meanings are as expressive as influential. Signs became a major driving force for advertisements, and the applicability of the literacy approach lies in its knowledge about the broader field of meaning-making (Barroso, 2020). In this world where videos, TV, and the internet have become the primary and pervasive sources for education and literacy, learning to read and write the printed word is still vital but will no longer be sufficient. There is an urge for educators and practitioners to help students use visual language and the language of the screen to decode and encode audio-visual messages in the production of the news story (Jhaveri, 2011).

At present, it is vital to assess our students whether they have the skills and tools to evaluate a huge amount of information, much of which is tucked into their newsfeeds. Given the paramount independence, they decide on what to read, share, and believe. Without the facility to evaluate this random information, like visual literacy, spreaders of fake news and malicious information will continue to proliferate who will deliberately make misleading information intended to influence public opinion or obscure facts (Thompson, 2018). Overall, the semiotic analysis paves the way for a thorough and systematic approach in looking into the meaning of signs around us, which is on the denotative meaning, connotative meaning, and myth of the photos. This inquiry can also be associated with the development of the students' visual literacy, especially with regard to the social issues in the country.

\section{Research Design}

In this study, I employed a qualitative descriptive method, particularly a phenomenological approach in gathering relevant data. Also, semiotic analysis was used to answer the semiotic features of online news photographs guided by three semiotic theories: Semiotics Theory of Ferdinand de Saussure (1959), the theory of Order of Signification proposed by Roland Barthes (1977), and Social Semiotics of Halliday (1978).

The qualitative approach emphasized the qualities of entities, processes, and meanings that are not experimentally examined or measured in terms of quantity, amount, intensity, or frequency. The research questions often stressed how social experience is created and given meaning. In this case, an in-depth interpretation of the sign in online news photographs was analyzed. One example of the social experiences was the issues in our society posted on various online news platforms; hence, this study aimed to analyze pictures to give relevant meaning and analysis in the present context. The value-laden nature of such inquiry stresses the relationship between the researcher and subject and the situational constraints that shape the inquiry (Denzin, 2010). Aside from identifying the semiotic features, I also touched on the value-laden nature of the investigation by citing the effects of these news photographs in their personal viewpoints and soliciting the students' reflections on the present phenomenon experiencing by humanity, in general.

Next, descriptive research describes a phenomenon and its characteristics, usually in its natural setting, without experimentation (Nassaji, 2015). The descriptive method is the method that is used to find the elements, criteria, and characteristics of the phenomenon. This method will start with collecting, analyzing, and 
interpreting the research materials, which are the online news photographs. This study employed the semiotic analysis, which used the semiotics approach to explain the signs present in online news photographs, its denotative and connotative meanings, and the myths conveyed from these photos.

Moreover, this qualitative study used a phenomenological approach involving interviews with the participants who were senior high school students. Qualitative research, in general, refers to inductive, holistic, emic, subjective, and process-oriented methods used to comprehend, interpret, and describe a phenomenon. It is a systemic, subjective approach used to describe meaning (Burns \& Grove, 2003). By making use of in-depth interviews and focus group discussions, the study examined the social meanings that the students obtained by analyzing online news photographs in the Philippine context.

In addition, according to Lester (1999), the purpose of the phenomenological study was to gather information and perceptions through inductive, qualitative methods like interviews and discussions representing it from the viewpoint of the research participants. This study called for the students to probe their deep understanding of significant matters through analysis of online news photographs. Through the interviews conducted, the phenomena were discussed, analyzed, and interpreted through the semiotic lens. Lastly, semiotic analysis was used to answer the semiotic features of online news photographs. It described the connotative, denotative, and myth of each of the pictures. In semiotics, it is necessary to circumscribe, define and describe the object to find explanations for its qualities (Yucel, 2019). This analysis revealed the deeper meaning of the photos concerning the Philippine context. Thus, culture gives us tools to interpret the world around us. It is the aggregate process by which meanings are created, stored, and transferred, and norms and values are constituted (Mortelmans, 1998).

\subsection{Research Materials}

The nature of this study called for an appropriate selection of research materials. In this study, the materials used were photographs from online news websites. Photos can be edited and manipulated, so I made sure that these photographs reflect accuracy and truthfulness to them; thus, the popular and trusted online news sources were the appropriate choice to secure the integrity of the said photos. Therefore, I chose pictures from the top five general news publishers in the Philippines according to Wong (2019), namely ABS-CBN, Philippine Daily Inquirer, Rappler, Philippine Star, and Manila Bulletin. Additionally, these websites garnered the most monthly web visits and received millions of likes from Facebook.

According to Braun and Clarke (2013), the ideal number for entries in a corpora-based study is 10-100 sources. Thus, I selected fifteen (15) online news photographs to be analyzed and interpreted. I chose the news photographs in the Philippine context and disregarded photos that present news in another setting and context. Also, at the bottom part of every photo, the source was cited and appropriately acknowledged. To observe the relevance of the study to the present times, the gathered materials were from January 2020 to December 2020 for it to be part of the study. Overall, I selected two online photographs from Philippine Daily Inquirer, four photos from Philippine Star, three photos from Manila Bulletin, four pictures from ABS-CBN News, and two photos from Rappler.

\subsection{Research Participants}

This qualitative study had fourteen (14) student-participants from the senior high school department of a particular secondary school in the Division of Davao de Oro. Creswell (1998) recommends 5-25 participants for qualitative research to saturate and obtain enough data to sufficiently describe the phenomenon of interest and address the research questions. There were seven senior high school students for the In-Depth Interview (IDI) and seven student-participants for Focus Group Discussion (FGD). All of these identified participants were currently enrolled in the HUMSS strand. I was confident that this number of participants sufficed the needed information about the subject that I investigated.

12 Consortia Academia Publishing (A partner of Network of Professional Researchers and Educators) 
Purposive sampling is a technique used to identify and select information-rich cases for the most effective use of limited resources (Patton, 2002). Hence, this study used purposive sampling in choosing the participants. The inclusion criteria to be qualified as a participant were the following: (1) a bona fide senior high school student, (2) a Grade 12 HUMSS student for S.Y. 2020-2021, and (3) a student who already took up English subjects namely, English for Academic and Professional Purposes, Reading and Writing, and Oral Communication in Grade 11. A participant can withdraw anytime if he/she decides not to be part of the study by not filling up the consent form given by the researcher, or he/she may withdraw his consent at any time and discontinue participating in the study without penalty. He/she is not waiving any legal claims, rights, or remedies because of his/her participation in this research study.

Further, students who were not enrolled in the secondary school where the study was conducted and mentally unstable were excluded. Students who were not willing to participate in the study and who were not present during the data collection were not part of the conduct of this study. Specifically, I selected students in HUMSS because of the competencies they need to be equipped, especially in bringing about societal changes in the future. Likely, these students need to develop knowledge and skills in bringing about positive change through the study of social science theories and concepts and community-based realities (Mirriam College, 2020). As the study focused on societal issues, it fitted for them to answer relevant questions to find out their knowledge on the matter and for the teachers to understand how semiotic features to aid in the students' visual literacy.

\subsection{Data Collection}

In gathering the data, I followed these procedures: The first stage was the collection of fifteen news photographs in online newspapers and journals. I ensured the recency and accuracy of these photos by collecting only the photos posted or published from January 2020 to December 2020, and the said photos reflect the current events in the Philippine context. I disregarded those photos from another setting. Next, guided by the semiotics theory of de Saussure (1959) and theory of signification of Barthes (1977), I identified the features for each of the fifteen (15) photos by citing the signifier and signified and then specifically determining the denotative, then the connotative and the myth of the photos. This was presented in a tabular form to keep the organization of ideas. To make the analyzed data valid and reliable, an expert in linguistics's recommendations was sought to become the reviewer of the analyzed data.

The second stage of this qualitative study was on the interview of the participants I purposely selected. Initially, I asked for permission from the Schools Division Superintendent to conduct a study at a particular school under her supervision. Then, I asked for permission from the said school principal where my data collection was conducted. Next, I asked my prospect participant if he/she is willing to be interviewed after knowing the purpose of the study. This ensured that participants joined voluntarily and not a result of undue inducement. Then, the informed consent and assent form was distributed to the research participants both in an in-depth interview and focus group discussions to ensure that proper permission has been made.

I used multilingual in interviewing the students. They answered in their most comfortable language (English, Filipino, or Bisaya) or a mix of any of these three languages. I conducted a mock interview with two of the students in senior high school to prepare my art of questioning and make sure that participants understood the questions and answered it confidently and directly. During the interview, I made sure that participants can freely and comfortably share their insights. I asked for their permission to have an audio recording of the interview, provided that their names and other personal information remained confidential. This can be done by assigning pseudonyms to each of the participants to conceal their identity.

Due to some constraints, especially during this COVID-19 pandemic, I had decided to conduct the in-depth interview and focus group discussion online. This was to ensure that no participants will be at risk during the conduct of the activity. Since it is done online, I made it certain that the students were prepared beforehand regarding their internet connectivity so that a smooth and clear flow of discussion among the participants was 
established. The Google Meet, a video-communication service developed by Google, was utilized to gather relevant data from the participants. If there were some aspects in the interview where their answers were not clear to me, I repeated the questions to confirm their answers. In an in-depth interview and focus group discussion, each participant was asked semi-structured and generally open-ended questions. Lastly, the data were coded, analyzed, and reduced into essential themes.

\subsection{Data Analysis}

Firstly, to address the question under semiotic analysis, the collected photos were analyzed in the form of discussion tables where it employed the Order of Signification by Roland Barthes (1977). The tabular discussion started with presenting the signifier, signified, then, followed by a denotative meaning in descriptive explanation, connotative meaning to comprehend profound meanings, lastly, the identification of myth in accordance with the Philippine context. In order to guarantee the reliability and validity of the analyzed data from these photos, I sought the expertise of a Doctor in Applied Linguistics who would become the reviewer of the analyzed data. In analyzing the data from the interview, I followed the qualitative data analysis of Miles and Huberman (1994), which has three elements: data reduction, data display, and conclusion drawing. This is important to extract necessary and relevant results. Initially, data reduction referred to the process of selecting, focusing, and simplifying the data that appear in interview transcriptions. This is done to make the data manageable and intelligible in terms of issues being addressed.

Secondly, data display provided an organized and compressed collection of information to pave the way for conclusion drawing. It allows the analyst to extrapolate from the data enough to begin to discern systematic patterns and interrelationships. At this stage, themes may emerge. Speaking of themes, the participants' reduced data from the interview were analyzed using thematic analysis. I followed the suggested steps of thematic analysis by Braun and Clarke (2006). In their framework, data underwent six phases: familiarizing, coding, 'searching' for themes, reviewing themes, defining, naming them, and writing the report. Lastly, conclusion drawing involves considering what the analyzed data mean and assessing their implications for the research questions at hand. It entails revisiting the data as many times as necessary to cross-check or verify these emergent conclusions (Atkinson \& Delamont, 2006). These conclusions emerged from the formulated themes from the responses of the research participants as an instrument for results and discussions.

\subsection{Ethical Considerations}

Ethical considerations serve as a guidepost in the conduct of this study. As stated by Cormack (2016), the first duty of the researcher is to ensure that the researcher shall have no harm to anyone. Thus, to abide by the ethical standards, the Belmont Report of the National Commission for the Protection of Human Subjects of Biomedical and Behavioral Research (1979) summarizes general ethical principles and guidelines for research involving human subjects as identified by the Commission. In its deliberations, three core principles are identified: respect for persons, beneficence, and justice. These principles are further specified to the following applications: informed consent, assessment of risks and benefits, and section of subjects. Additionally, the following research guidelines and standardized criteria were guaranteed.

Voluntary Participation. This principle entails that participants are not coerced into participating in the study (Trochim, 2020). As the researcher, I ensured that participants feel that they have the freedom to involve themselves in the study. Firstly, participants were informed about the procedures involved in the study, and they gave their consent to participate. During the interview, participants could withdraw their full participation at any point in time without penalty, and they had the choice not to answer some questions I asked them. Participants were not waiving any legal claims, rights, or remedies because of their participation in this research study. Also, the purpose of the study was clearly explained to them to gain their trust and willingness to participate. They were assured that their participation served as a meaningful contribution to the study's completion and success. 
Privacy and Confidentiality. This standardized criterion helps to protect participant's privacy. It assures that identifying information will not be made available to anyone directly involved in the study (Trochim, 2020). My main task, as a researcher, is to maintain this fundamental right of my participants by not disclosing to the public and other institutions their names, addresses, contact numbers, and other personal information. Further, this personal information was not revealed in the processes such as data collection, analysis, and reporting of research findings.

Informed Consent Process. Closely related to the notion of voluntary participation in the process of obtaining informed consent from the participants. This means that research participants must be fully informed about the procedures and risks involved in research and must give their consent to participate. As the researcher, first, I sent a letter to the educational authorities seeking their permission to conduct my study in their area of supervision. Upon receiving the approval, I explained to my participants the research purpose, potential risks, and benefits to give them an overview of the direction of the study. Explaining such information to the participants and allowing them to comprehend the research process was vital in the study's goals. Lastly, securing the signed informed consent form was made to prove the participants' consent (Arifin, 2018).

\section{Results}

The fourteen participants were the Grade 12 students at a certain public high school in Davao de Oro who shared various analyses and insights on online news photographs. In-Depth Interview and Focus Group Discussion was conducted to each participant through Google Meet.

This section provides the details of the results of the qualitative analysis to answer the following research questions:

$>\quad$ What are the semiotic features present in online news photographs?

$>\quad$ How does students' understanding of online news photographs affect their viewpoints regarding issues in society?

$>\quad$ How do the semiotic features of online news photographs aid in the visual literacy of students?

This section is divided into four parts. The first part was all about the data of the participants from which the qualitative data were assembled. The second part discussed the data analysis dealings and the steps in the classifications of the emergent themes collected from the in-depth interviews and focus group discussion. The third part dealt with analyzing semiotic features from online news photographs and answers to the in-depth interviews and the focus group discussion questions under each research problem. Lastly, part four included the outline of responses from the different participants.

\subsection{Participants}

Key Informants. There were fourteen key informants in this study, four male and ten females, who were all identified as Grade 12 senior high school students aged 17-19 in a certain school in Maco North District, Division of Davao de Oro. I believe it helped a lot that I knew my participants as I became one of their subject teachers in an English subject when they were in Grade 11. Hence, it was easier for me to gain their trust and build rapport with them. They were selected by their willingness to be interviewed based on their critical comprehension of semiotic analysis of online news photographs and were personally validated by my gatekeeper, the school's English coordinator. The participants were given pseudonyms to preserve confidentiality and privacy, as presented in Table 1.

Focus Group. The FGD (Focus Group Discussion) is a method used to understand an issue or topic thoroughly. Primarily, the data collected is from purposely chosen individuals who have first-hand experience regarding the matter. For this study, the focus group discussion was conducted in one meeting that was set on the 
scheduled date approved by the participants. It was also beneficial on my part because some of the participants were already acquainted with each other which made it easier for them to share their thoughts with the group. My focus group was composed of senior high school students, particularly in Grade 12 level. The discussion was conducted to obtain further perspectives and critical understanding and build social constructions on participants' thoughts, opinions, and reactions about semiotic analysis of online news photographs. To observe confidentiality, pseudonyms were used to make their identity obscure. They were presented in Table 1 according to their number. They were able to sufficiently give the best answer they can in every question I asked to them. The key informants and the participants in the focus group discussion answered the same set of interview questions.

\section{Table 1}

Participants' Information

\begin{tabular}{|c|c|c|c|c|}
\hline Pseudonym & Age & Gender & Educational Level & Study Group \\
\hline Grasya & 18 & Female & Grade 12 & In-depth Interview \\
\hline Red & 17 & Female & Grade 12 & In-depth Interview \\
\hline Flower & 17 & Female & Grade 12 & In-depth Interview \\
\hline Jennsie & 18 & Female & Grade 12 & In-depth Interview \\
\hline Blitzkrieg & 18 & Male & Grade 12 & In-depth Interview \\
\hline Tricky & 18 & Female & Grade 12 & In-depth Interview \\
\hline Yowkai & 18 & Female & Grade 12 & In-depth Interview \\
\hline Blckmale & 17 & Male & Grade 12 & Focus Group \\
\hline Johan & 18 & Male & Grade 12 & Focus Group \\
\hline Aphrodite & 18 & Female & Grade 12 & Focus Group \\
\hline Dolores & 17 & Female & Grade 12 & Focus Group \\
\hline Sunset & 18 & Male & Grade 12 & Focus Group \\
\hline Sagittarie & 19 & Female & Grade 12 & Focus Group \\
\hline Eleven & 18 & Female & Grade 12 & Focus Group \\
\hline
\end{tabular}

The interviews were conducted through Google Meet making sure that each participant has a stable and strong connection at their own places. Furthermore, I passed the photographs three days before the interview to give my participants ample time to examine the photos. I used the recording feature of Google Meet. I also employed personal notetaking of the answers that I thought were important and wrote down salient observations during the interviews.

\subsection{Categorization of Data}

Firstly, to address the questions under semiotic analysis, the fifteen selected online news photographs were analyzed in the form of discussion tables. The tabular discussion started with presenting the news photographs, followed by a denotative meaning in descriptive explanation, connotative meaning to comprehend profound meanings, and lastly, the identification of myth according to the Philippine context. The analysis was then subjected to the checking and recommendation of the linguistic professional. Secondly, in-depth interviews and the focus group discussion addressed the second and third research questions. The audio data from the recordings were directly transcribed, and answers in vernacular were carefully translated into English. I first listened cautiously to the sound recordings. This was to transform the data into texts and so that it would be easier for me to code my data later. Three steps were taken during the data analysis: data reduction, data display, drawing conclusions, and verification (Miles \& Huberman, 1994). These were done to identify core and essential themes about the phenomenon under the investigation.

Thematic analysis was the approach used in pairing and separating data, a way of sorting and categorizing. The lengthy and large volumes of qualitative data gathered are consolidated and manageable, easier to control, and understood through data reduction. I also asked for assistance from a professional who was an expert on analyzing data. The next step was displaying data through graphic organizers such as a matrix or table for the viewer to draw a conclusion. In this step, I read my data several times to get acquainted with them. At first, I found several themes, but with the help of a data analyst, the themes were narrowed down to just a few ones. Lastly, drawing conclusions and verification were done for qualitative analysis. This was going back several 
more times and revisiting the analyzed data to see the emergent conclusions' validity completely. The data conversed through the emergence of conceptual categories and descriptive themes. The theme serves as an implicit topic that organizes a group of repeating ideas, enabling researchers to answer the research questions (Vaismoradi, 2015). Afterward, I interpreted the conceptual categories and examined the transcriptions. I considered the comments and suggestions, such as deleting data that are not substantial to the study.

\subsection{Research Question No. 1. What are the semiotic features present in online news photographs?}

The semiotic features were analyzed and categorized based on the semiotics theory of de Saussure (1959) and the theory of Order of Signification of Roland Barthes (1977). Hence, the tabular discussion showed the presentation of semiotic features according to signifier, signified, denotation, connotation, and myth. The signifier is the material aspect of the sign, while the signified is considered the mental concept. In this study, the signifier refers to the online news photographs, while the signified refers to the mental concept formed upon seeing the signifier. The denotative meaning of news photos determines the visual elements like people, environment, and objects present in a photo. The connotative meaning will look into the profound meaning of these photos beyond what the obvious signs in a photo suggest. Lastly, myth indicates the general meaning of the photos in relation to the Philippine culture and setting. Overall, there were fifteen online news photographs subjected for analysis from the five prominent Philippine news websites. Specifically, there were two (2) photos from Philippine Daily Inquirer, four (4) photos from Philippine Star, three (3) photos from Manila Bulletin, four (4) photos from ABS-CBN News, and two (2) photos from Rappler.

Table 2

Semiotic Features on Online News Photographs

\begin{tabular}{|c|c|c|c|c|}
\hline Signifier & Signified & Denotation & Connotation & Myth \\
\hline $\begin{array}{l}\text { (See Appendices for the details of the } \\
\text { photograph) } \\
\text { ONP-01 } \\
\text { Two children are carrying two wooden } \\
\text { chairs. }\end{array}$ & $\begin{array}{l}\text { Children's } \\
\text { struggle due to } \\
\text { flood }\end{array}$ & $\begin{array}{l}\text { Two children are } \\
\text { carrying two } \\
\text { wooden chairs, } \\
\text { one chair on top } \\
\text { of the other. One } \\
\text { half-naked boy is } \\
\text { leading the way } \\
\text { by holding one } \\
\text { arm of the chair, } \\
\text { and the other } \\
\text { child is following } \\
\text { his lead while } \\
\text { holding the } \\
\text { opposite arm of } \\
\text { the chair. The } \\
\text { ground is damp } \\
\text { and muddy. The } \\
\text { surrounding is } \\
\text { cluttered with } \\
\text { random objects. }\end{array}$ & $\begin{array}{l}\text { The diagonal } \\
\text { posture of the } \\
\text { half-naked boy } \\
\text { transferring the } \\
\text { heavy chairs } \\
\text { displays } \\
\text { determination and } \\
\text { hard work. The } \\
\text { chairs signify the } \\
\text { burden they are } \\
\text { carrying. Also, the } \\
\text { flood with thick } \\
\text { mud reflects the } \\
\text { struggling situation } \\
\text { of a place recently } \\
\text { hit by a typhoon. } \\
\text { As the two boys are } \\
\text { lifting the chairs, it } \\
\text { implies a value of } \\
\text { being helpful and } \\
\text { teamwork of } \\
\text { Filipinos. } \\
\text { The photo depicts } \\
\text { the difficult } \\
\text { situation of the } \\
\text { people living in the } \\
\text { area, especially } \\
\text { after the typhoon. }\end{array}$ & $\begin{array}{l}\text { Since the } \\
\text { Philippines is } \\
\text { prone to } \\
\text { typhoons, } \\
\text { Filipino } \\
\text { children are } \\
\text { accustomed to } \\
\text { the difficult } \\
\text { situation } \\
\text { brought about } \\
\text { by it. Thus, } \\
\text { even at an } \\
\text { early age, they } \\
\text { can } \\
\text { sympathize } \\
\text { with their } \\
\text { neighbors; that } \\
\text { is why helping } \\
\text { one another is } \\
\text { instinctive to } \\
\text { them. }\end{array}$ \\
\hline
\end{tabular}




\begin{tabular}{|c|c|c|c|c|}
\hline Signifier & Signified & Denotation & Connotation & Myth \\
\hline $\begin{array}{l}\text { (See Appendices for the details of the } \\
\text { photograph) } \\
\text { ONP-02 } \\
\text { People riding a cart on the railway }\end{array}$ & $\begin{array}{l}\text { The status of the } \\
\text { rich and the } \\
\text { poor }\end{array}$ & $\begin{array}{l}\text { There are five } \\
\text { people on the } \\
\text { railway who wear } \\
\text { face masks on the } \\
\text { cart. Sitting on } \\
\text { the far-right side } \\
\text { of the cart, } \\
\text { waving, is Vice } \\
\text { President Leni } \\
\text { Robredo. People } \\
\text { look and wave at } \\
\text { them beside the } \\
\text { railway. }\end{array}$ & $\begin{array}{l}\text { Upon seeing the } \\
\text { country's vice } \\
\text { president on a very } \\
\text { humble cart, people } \\
\text { wave at her to show } \\
\text { their amiable and } \\
\text { welcoming } \\
\text { personality. The } \\
\text { vice president on } \\
\text { the cart waves back } \\
\text { at them to show her } \\
\text { appreciation. } \\
\text { The photo radiates } \\
\text { a sense of modesty } \\
\text { and simplicity. }\end{array}$ & $\begin{array}{l}\text { As a politician, } \\
\text { one way to } \\
\text { secure } \\
\text { approval and } \\
\text { be } \\
\text { remembered } \\
\text { by the } \\
\text { constituents is } \\
\text { to be like a } \\
\text { common } \\
\text { person doing } \\
\text { daily, typical } \\
\text { tasks of an } \\
\text { ordinary } \\
\text { citizen. }\end{array}$ \\
\hline $\begin{array}{l}\text { (See Appendices for the details of the } \\
\text { photograph }) \\
\text { ONP-03 } \\
\text { People riding on a rubber boat }\end{array}$ & $\begin{array}{l}\text { Volunteerism } \\
\text { during crisis }\end{array}$ & $\begin{array}{l}\text { Eight people } \\
\text { wearing face } \\
\text { masks ride a } \\
\text { rubber boat on a } \\
\text { flooded, urban } \\
\text { street where } \\
\text { electric wires are } \\
\text { loosely dangling. } \\
\text { The PNP, BFP } \\
\text { personnel, and } \\
\text { civilians, whose } \\
\text { half of the body is } \\
\text { submerged in } \\
\text { flood, support } \\
\text { every side of the } \\
\text { boat to prevent it } \\
\text { from capsizing. }\end{array}$ & $\begin{array}{l}\text { People on an } \\
\text { overloaded rubber } \\
\text { boat struggles for } \\
\text { survival. The } \\
\text { people helping } \\
\text { them depicts } \\
\text { volunteerism and } \\
\text { unity. The photo } \\
\text { conveys the } \\
\text { message that } \\
\text { nobody should be } \\
\text { left behind and that } \\
\text { people, no matter } \\
\text { their position in } \\
\text { society, are willing } \\
\text { to help those in } \\
\text { need. } \\
\text { Also, people never } \\
\text { forget to wear their } \\
\text { face masks which } \\
\text { shows that they still } \\
\text { value their health } \\
\text { and the health of } \\
\text { others. }\end{array}$ & $\begin{array}{l}\text { Helping people } \\
\text { who are in } \\
\text { need is typical } \\
\text { to Filipinos, } \\
\text { especially } \\
\text { when natural } \\
\text { disasters strike. }\end{array}$ \\
\hline $\begin{array}{l}\text { (See Appendices for the details of the } \\
\text { photograph) } \\
\text { ONP-04 } \\
\text { A woman wearing a crown while waving }\end{array}$ & $\begin{array}{l}\text { Beauty queens } \\
\text { bring pride to } \\
\text { the country and } \\
\text { enjoyment to } \\
\text { Filipinos. }\end{array}$ & $\begin{array}{l}\text { A woman in a red } \\
\text { Filipiniana gown } \\
\text { with a crown and } \\
\text { a white sash on } \\
\text { her shoulders } \\
\text { which states, } \\
\text { "Miss Universe," } \\
\text { is waving her left } \\
\text { hand while } \\
\text { holding a red rose } \\
\text { on her right hand. } \\
\text { The smiling } \\
\text { woman is } \\
\text { wearing a face } \\
\text { shield, and she is } \\
\text { surrounded by } \\
\text { colorful flowers. }\end{array}$ & $\begin{array}{l}\text { The smile on the } \\
\text { woman's face } \\
\text { behind the face } \\
\text { shield represents } \\
\text { Filipino's resiliency } \\
\text { and positive } \\
\text { outlook amidst the } \\
\text { problems of the } \\
\text { country. The rose } \\
\text { she is holding and } \\
\text { the flowers } \\
\text { surrounding her are } \\
\text { related to the } \\
\text { concept of } \\
\text { femininity and } \\
\text { graciousness. } \\
\text { While wearing the } \\
\text { silver crown on her } \\
\text { head, she is waving } \\
\text { towards an } \\
\text { audience which } \\
\text { expresses the idea } \\
\text { that she appreciates } \\
\text { and recognizes } \\
\text { their support for her }\end{array}$ & $\begin{array}{l}\text { Beauty } \\
\text { pageant gives } \\
\text { joy and } \\
\text { excitement to } \\
\text { Filipinos. A } \\
\text { candidate with } \\
\text { a crown } \\
\text { radiates the } \\
\text { spirit of hope } \\
\text { and positivity } \\
\text { to Filipinos. }\end{array}$ \\
\hline
\end{tabular}

18 Consortia Academia Publishing (A partner of Network of Professional Researchers and Educators) 
Looking at the bigger picture: A semiotic analysis on online news photographs

\begin{tabular}{|c|c|c|c|c|}
\hline & & & $\begin{array}{l}\text { to get the coveted } \\
\text { crown. }\end{array}$ & \\
\hline $\begin{array}{l}\text { See Appendices for the details of the } \\
\text { photograph) } \\
\text { ONP-05 } \\
\text { People are on the street with a signage } \\
\text { stating "Konting Tulong po sa mga Driver" }\end{array}$ & $\begin{array}{l}\text { The parents } \\
\text { struggle to feed } \\
\text { their families. }\end{array}$ & $\begin{array}{l}\text { A woman is on } \\
\text { the street carrying } \\
\text { her son. One man } \\
\text { wearing a face } \\
\text { mask extends his } \\
\text { arm while } \\
\text { holding an empty } \\
\text { plastic gallon } \\
\text { container. There } \\
\text { is another man, } \\
\text { wearing a } \\
\text { checkered, } \\
\text { sleeveless shirt, } \\
\text { sitting on the } \\
\text { floor of the } \\
\text { jeepney. There } \\
\text { are two signs in } \\
\text { front of them, } \\
\text { stating "Konting } \\
\text { Tulong po sa mga } \\
\text { Driver" and "No } \\
\text { Parking". }\end{array}$ & $\begin{array}{l}\text { Based on the two } \\
\text { men's appearance } \\
\text { and posture, they } \\
\text { are family men and } \\
\text { must provide for } \\
\text { the needs of the } \\
\text { family. The man } \\
\text { holding an empty } \\
\text { plastic gallon } \\
\text { container signified } \\
\text { an act of asking for } \\
\text { a small help from } \\
\text { vehicles and } \\
\text { passers-by, as } \\
\text { evidenced by the } \\
\text { sign written on } \\
\text { cardboard in front } \\
\text { of him. The other } \\
\text { man in a sleeveless } \\
\text { shirt resorted to } \\
\text { sitting on the floor } \\
\text { of the jeepney } \\
\text { instead of the } \\
\text { driver's seat, } \\
\text { signifying that they } \\
\text { cannot do their } \\
\text { regular job because } \\
\text { of the restrictions } \\
\text { caused by the } \\
\text { pandemic. The } \\
\text { sullen-faced } \\
\text { woman is casually } \\
\text { standing on the side } \\
\text { of the street } \\
\text { carrying her baby } \\
\text { as if waiting for } \\
\text { something. }\end{array}$ & $\begin{array}{l}\text { Parents will do } \\
\text { anything to } \\
\text { provide food } \\
\text { for the family, } \\
\text { even to the } \\
\text { point of } \\
\text { begging. }\end{array}$ \\
\hline $\begin{array}{l}\text { (See Appendices for the details of the } \\
\text { photograph) } \\
\text { ONP-06 } \\
\text { A police assistance desk beside the beach }\end{array}$ & $\begin{array}{l}\text { Safety and } \\
\text { security must be } \\
\text { upheld } \\
\text { whenever and } \\
\text { wherever. }\end{array}$ & $\begin{array}{l}\text { A man at the } \\
\text { police assistance } \\
\text { desk is stationed } \\
\text { beside the clear, } \\
\text { blue beach with } \\
\text { white sand. The } \\
\text { help desk is } \\
\text { located between } \\
\text { two coconut } \\
\text { trees. The } \\
\text { atmosphere is } \\
\text { bright. }\end{array}$ & $\begin{array}{l}\text { The sunny and } \\
\text { inviting ambiance } \\
\text { of the beach depicts } \\
\text { a feeling of } \\
\text { calmness and } \\
\text { freshness. The } \\
\text { police assistance } \\
\text { desk amid this } \\
\text { serenity radiates a } \\
\text { sense of security to } \\
\text { the place. }\end{array}$ & $\begin{array}{l}\text { Wherever one } \\
\text { goes, feeling } \\
\text { safe and } \\
\text { secured is } \\
\text { important to } \\
\text { enjoy a place } \\
\text { truly. }\end{array}$ \\
\hline
\end{tabular}


Moldez, C., \& Gomez, D.

\begin{tabular}{|c|c|c|c|c|}
\hline Signifier & Signified & Denotation & Connotation & Myth \\
\hline $\begin{array}{l}\text { (See Appendices for the details of the } \\
\text { photograph) } \\
\text { ONP-07 } \\
\text { Women in pink uniforms wearing face } \\
\text { shield and face mask }\end{array}$ & $\begin{array}{l}\text { Teachers } \\
\text { continue to } \\
\text { provide } \\
\text { education in } \\
\text { alternative } \\
\text { ways. }\end{array}$ & $\begin{array}{l}\text { One woman in a } \\
\text { pink uniform is } \\
\text { looking at the } \\
\text { other woman in a } \\
\text { ponytail. The } \\
\text { woman at the } \\
\text { center is lifting a } \\
\text { box. Other } \\
\text { women in the } \\
\text { background are } \\
\text { talking. }\end{array}$ & $\begin{array}{l}\text { These women in } \\
\text { pink uniforms are } \\
\text { teachers who are } \\
\text { busy preparing for } \\
\text { the packaging, } \\
\text { sorting, and } \\
\text { delivering } \\
\text { self-learning } \\
\text { modules (SLM). } \\
\text { The photo candidly } \\
\text { describes the duty } \\
\text { of teachers who are } \\
\text { extra cautious in } \\
\text { carrying out their } \\
\text { tasks as front liners } \\
\text { in education, for } \\
\text { they are wearing } \\
\text { their face masks } \\
\text { and face shields. }\end{array}$ & $\begin{array}{l}\text { Education } \\
\text { must continue } \\
\text { despite } \\
\text { pandemic. }\end{array}$ \\
\hline $\begin{array}{l}\text { (See Appendices for the details of the } \\
\text { photograph) } \\
\text { ONP-08 } \\
\text { A woman and child are taking a selfie in } \\
\text { front of Basilika ng Nazareno. }\end{array}$ & $\begin{array}{l}\text { Filipinos are } \\
\text { fond of taking } \\
\text { pictures, } \\
\text { especially on } \\
\text { special } \\
\text { occasions. }\end{array}$ & $\begin{array}{l}\text { A smiling woman } \\
\text { wearing a blue } \\
\text { t-shirt is raising } \\
\text { her right hand, } \\
\text { holding a phone. } \\
\text { The boy is } \\
\text { holding her right } \\
\text { wrist while } \\
\text { looking at the } \\
\text { same phone. A } \\
\text { middle-aged man, } \\
\text { wearing an } \\
\text { orange polo shirt } \\
\text { and looking } \\
\text { sideways, is } \\
\text { behind them. The } \\
\text { building has a } \\
\text { terrace where a } \\
\text { woman takes } \\
\text { down a red and } \\
\text { yellow curtain } \\
\text { along its fence. } \\
\text { Jesus Christ } \\
\text { statue is built on } \\
\text { the wall of the } \\
\text { building and } \\
\text { beside it is a } \\
\text { signage stating } \\
\text { "Ika-1 na Utos: } \\
\text { Ibigin mo ang } \\
\text { Diyos ng buong } \\
\text { puso, buong } \\
\text { kaluluwa at } \\
\text { lakas." }\end{array}$ & $\begin{array}{l}\text { The red and yellow } \\
\text { curtains being } \\
\text { taken down in the } \\
\text { background } \\
\text { signifies a recently } \\
\text { concluded } \\
\text { celebration of the } \\
\text { Traslacion of the } \\
\text { Black Nazarene. } \\
\text { The grinning } \\
\text { mother, with his } \\
\text { son taking a picture } \\
\text { in front of the } \\
\text { church, expresses } \\
\text { delight for the } \\
\text { occasion. }\end{array}$ & $\begin{array}{l}\text { The Catholic } \\
\text { church has } \\
\text { many religious } \\
\text { observances. } \\
\text { In festivities } \\
\text { and holidays, } \\
\text { Catholics feel } \\
\text { the joy and } \\
\text { excitement for } \\
\text { the event, and } \\
\text { they do not } \\
\text { forget to } \\
\text { capture these } \\
\text { moments by } \\
\text { taking photos. }\end{array}$ \\
\hline
\end{tabular}




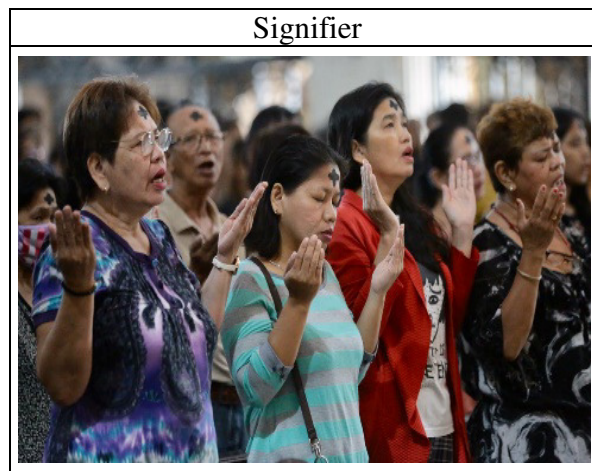

(See Appendices for the details of the photograph)

\section{ONP-09}

People with a cross marking on their foreheads are praying

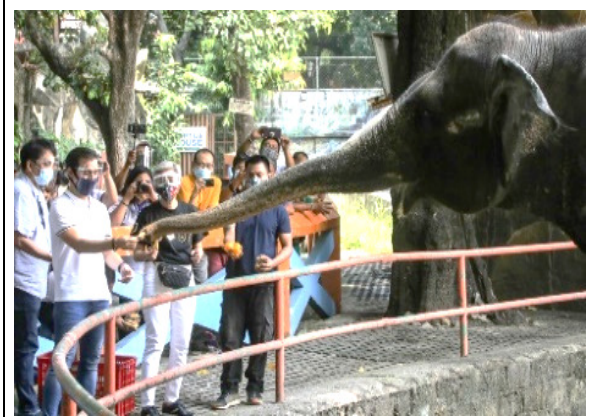

(See Appendices for the details of the photograph)

ONP-10

A man wearing a white polo shirt is feeding the elephant.

\begin{tabular}{|l|l|}
\multicolumn{1}{|c|}{ Signified } & \multicolumn{1}{c|}{ Denotation } \\
\hline $\begin{array}{l}\text { Filipinos are } \\
\text { prayerful. }\end{array}$ & $\begin{array}{l}\text { A middle-aged } \\
\text { woman wearing a } \\
\text { blend of black }\end{array}$ \\
\hline
\end{tabular}

and violet blouse

is closing her

eyes, opening her

mouth, and lifting

her hands. A

woman in her 30s

is wearing a

checkered,

long-sleeved shirt

is next to her,

who also lifts her

hands and shuts

her eyes. The

woman in a red

blazer is lifting

her hands as well

while looking

above and

opening her

mouth. The

woman beside

her, wearing a

black blouse,

closes her eyes

intently while

lifting her hands.

All of them have

cross markings on

their forehead.

A government

official is the

initiator of good

deeds.

The elephant is

extending its long

trunk to the hand

of a man in a

\begin{tabular}{l|l}
\multicolumn{1}{c|}{ Connotation } & \multicolumn{1}{c}{ Myth } \\
$\begin{array}{l}\text { This scene clearly } \\
\text { expresses the faith } \\
\text { of the people by } \\
\text { praying intently } \\
\text { and singing } \\
\text { passionately. With }\end{array}$ & $\begin{array}{l}\text { Catholics } \\
\text { attend the Ash } \\
\text { Wednesday } \\
\text { mass as one } \\
\text { their eyes, this } \\
\text { signifies that they }\end{array}$ \\
way to profess \\
their faith. \\
Filipinos are \\
known to be \\
religious.
\end{tabular}

want to block out

distractions and

focus on their

conversation with

God. The cross of

ashes on the

forehead shows that

it is the start of

Lent, 40 days of

penance for

Christians

worldwide.

white polo shirt

who is Mayor

Isko Moreno.

Right outside the

fence where the

elephant is

situated, a small

crowd is all

wearing face

masks and face

shields. They are

taking pictures

and videos on the

feeding activity

of the man to the

elephant.
The city mayor

who is feeding the

elephant presents a message to take

care of the animals.

The balance of nature should be restored and sustained, and realizing the role of animals in the lives of humans is very important. The people taking photos on the feeding activity represent an idea that this kind of activity must be replicated by other people.
A government official must be a role model for others. 


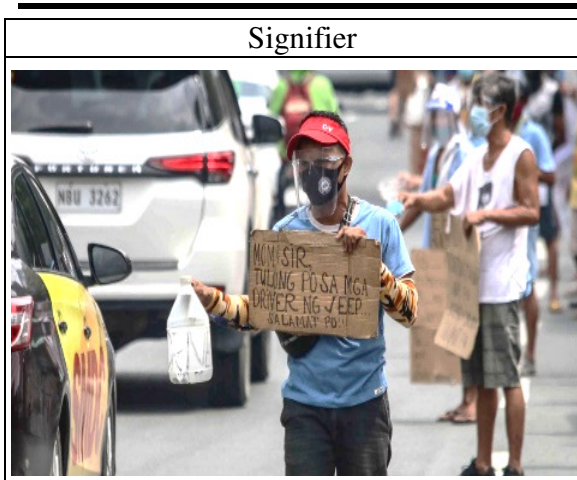

(See Appendices for the details of the photograph)

ONP-11

A man carrying an empty gallon container bottle while showing the cardboard with written words stating, "Mom \& Sir, Tulong po sa mga Driver ng Jeep. Salamat po."

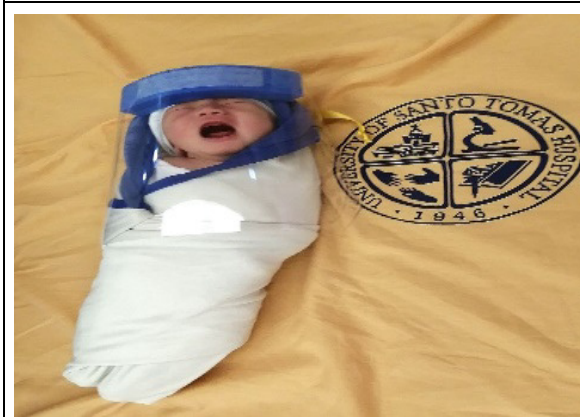

(See Appendices for the details of the photograph)

ONP-12

The baby wrapped in white linen is wearing a face shield

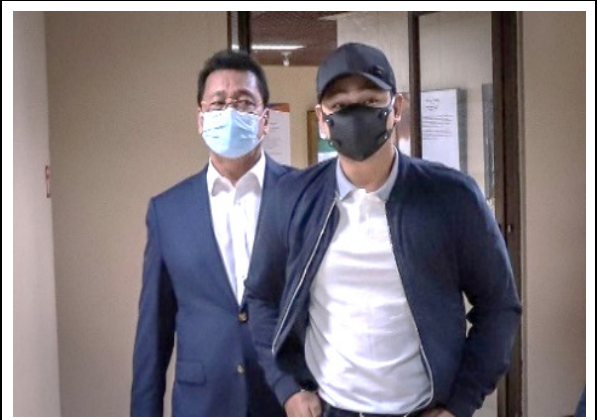

(See Appendices for the details of the photograph)

ONP-13

Two personalities wearing face mask
Signified

Drivers are

struggling to support their

families in this

time of

pandemic

Newborn babies

must be

protected

against the

virus.

Celebrities and politicians may share the same perspectives about various things.
Senator Lito

Lapid, on the left

side, is wearing a

navy-blue blazer

on top of a white

collared

button-down shirt

with his face

mask on. On the

right side, with

his face mask on,

is Coco Martin,

who is sporting a

black, zip-up

jacket with a

white polo shirt

underneath. They

are both walking

in the same

direction. \begin{tabular}{c|c} 
Connotation & Myth \\
\hline People are begging & Begging is not
\end{tabular}

for help, in

monetary form,

from the passing

vehicles for their

family's survival.

As stated in the

cardboard, it can be

implied that they

are drivers but

cannot do their day

job. This scene

captures the

perseverance and

dedication of the

providers of the

family, who are

usually the fathers,

just to feed their

family.

The crying baby

symbolizes new life

and new hope. The

white linen

wrapped around

him describes the

purity and

innocence of the

baby amidst the

problems, like

pandemic, we are

facing right now.

With the face shield

on, it conveys a

message that

newborns must be

taken care as they

are vulnerable to

the virus.

The two

personalities in two

contrasting fields,

politics and

showbiz industry,

have come

together. This

signifies that

anyone can unite

regardless of one's

position in society.

With their face

masks on, it shows

their obedience to

the set protocols.

Walking in the

same direction

conveys the idea

that both of them

are like-minded and

have similar

viewpoints

regarding issues in

society.
There is a big

difference

between

politics and

showbiz

industry. But

views and

opinions of

personalities

coming from

these two

different fields, agreement and

harmony are

possible. given the same 
Looking at the bigger picture: A semiotic analysis on online news photographs

\begin{tabular}{|c|c|c|c|c|}
\hline Signifier & Signified & Denotation & Connotation & Myth \\
\hline $\begin{array}{l}\text { (See Appendices for the details of the } \\
\text { photograph) } \\
\text { ONP-14 } \\
\text { A woman is holding plastic bags while } \\
\text { looking at the soldier }\end{array}$ & $\begin{array}{l}\text { Following the } \\
\text { rules and } \\
\text { regulations is } \\
\text { strengthened if } \\
\text { there are } \\
\text { persons in } \\
\text { authority } \\
\text { nearby. }\end{array}$ & $\begin{array}{l}\text { Beside the road, a } \\
\text { woman is } \\
\text { wearing a red } \\
\text { shirt, patterned } \\
\text { shorts, a face } \\
\text { mask, and an ID } \\
\text { with a sling } \\
\text { hanging on her } \\
\text { neck while } \\
\text { looking at the } \\
\text { soldier in full } \\
\text { gear. She is } \\
\text { holding two } \\
\text { plastic bags with } \\
\text { disposable lunch } \\
\text { packs inside. } \\
\text { Behind her is } \\
\text { another woman } \\
\text { wearing a blue } \\
\text { sleeveless shirt } \\
\text { and black pedal } \\
\text { pants, also } \\
\text { looking at the } \\
\text { soldier. }\end{array}$ & $\begin{array}{l}\text { The two women in } \\
\text { the photo holding } \\
\text { plastic bags depict } \\
\text { the typical } \\
\text { everyday image of } \\
\text { Filipinos who are } \\
\text { doing errands and } \\
\text { buying food for the } \\
\text { family. However, } \\
\text { wearing a face } \\
\text { mask and an ID } \\
\text { with a sling around } \\
\text { their necks portrays } \\
\text { an idea that they } \\
\text { need to comply and } \\
\text { follow first the } \\
\text { regulations set by } \\
\text { the government to } \\
\text { perform their } \\
\text { normal everyday } \\
\text { tasks. The soldier's } \\
\text { presence is a } \\
\text { reminder to the } \\
\text { people to obey and } \\
\text { uphold the rules } \\
\text { and regulations. }\end{array}$ & $\begin{array}{l}\text { Filipinos } \\
\text { follow the } \\
\text { rules, } \\
\text { especially if } \\
\text { there are } \\
\text { persons in } \\
\text { authority } \\
\text { keeping an eye } \\
\text { on them. }\end{array}$ \\
\hline $\begin{array}{l}\text { (See Appendices for the details of the } \\
\text { photograph) } \\
\text { ONP-15 } \\
\text { A man is wearing a face mask and looking } \\
\text { at the signage, states, "No Face Mask, No } \\
\text { Entry." }\end{array}$ & $\begin{array}{l}\text { Signages remind } \\
\text { everyone of the } \\
\text { things to do and } \\
\text { follow. }\end{array}$ & $\begin{array}{l}\text { A man wearing a } \\
\text { black t-shirt with } \\
\text { a blue sling on his } \\
\text { neck is looking at } \\
\text { the signage } \\
\text { posted on the } \\
\text { wall. In front of } \\
\text { him, a woman } \\
\text { with long hair } \\
\text { wearing a black } \\
\text { t-shirt enters the } \\
\text { door. The sign } \\
\text { beside the door, } \\
\text { posted on the } \\
\text { wall, states, "No } \\
\text { Face Mask, No } \\
\text { Entry." }\end{array}$ & $\begin{array}{l}\text { The woman on the } \\
\text { door complied with } \\
\text { the requirement } \\
\text { posted on the wall } \\
\text { that gives her } \\
\text { permission to enter } \\
\text { the door without } \\
\text { any problem. The } \\
\text { man behind her is } \\
\text { reading the sign } \\
\text { reminding himself } \\
\text { of the protocols to } \\
\text { follow. This } \\
\text { signifies his desire } \\
\text { to be compliant } \\
\text { with the } \\
\text { requirements. This } \\
\text { picture captures the } \\
\text { idea that people } \\
\text { must obey the rules } \\
\text { and regulations set } \\
\text { by the government. }\end{array}$ & $\begin{array}{l}\text { Posting } \\
\text { signages of } \\
\text { reminders on } \\
\text { the wall is an } \\
\text { essential } \\
\text { measure for } \\
\text { any } \\
\text { establishment } \\
\text { to remind their } \\
\text { employees of } \\
\text { the rules and } \\
\text { regulations } \\
\text { they need to } \\
\text { follow. }\end{array}$ \\
\hline
\end{tabular}

After scrutinizing the fifteen online news photographs, I was able to come up with their different levels of meaning as guided by the semiotics theory of Francis de Saussure and the theory of signification by Roland Barthes. As mentioned by the anchored theories, the semiotic features were categorized into the signifier, signified, denotation, connotation, and myth. The signifier refers to the photographs, while the signified identifies the mental representation of these signs. Further, denotation describes the obvious and literal meaning presented in the photos, while connotative meaning tackles the meaning of photos and how it evokes our emotions and sensibility. Lastly, myth states the meaning of photos in relation to our context in the Philippines. The norms, tendencies, and culture are taken into consideration to form a myth. Overall, the denotative meaning comes from the signifier and signified. The connotative meaning emerges from the denotation. Finally, these signifiers have denotative and connotative meanings, which build the myth of online news photographs.

The first signifier labeled as ONP-01 describes two children carrying two wooden chairs. The signified column stated that children are struggling due to floods. The denotation described the actions of the boy and their 
location wherein one half-naked boy is leading the way by holding one arm of the chair, and the other child is following his lead while holding the opposite arm of the chair. The ground is damp and muddy. Moreover, the photo connoted the difficult situation of the people living in the area. The myth of this photo focused on the idea that the Philippines, a tropical country, is prone to typhoons. Filipinos are accustomed to the difficult situation brought about by this natural calamity. Thus, they can sympathize with their neighbors; that is why helping one another is instinctive to them.

Next, the photo ONP-02 signifies people riding a cart on the railway. The signified column states the status of the rich and the poor. The denotation concentrated on the five people on the railway who wear face masks on the cart, wherein Vice President Leni Robredo is one of them. Beside the railway, people look and wave at them. The photo connoted a sense of modesty and simplicity that even a second-highest executive official of the government can understand and sympathize with the situation of an ordinary citizen. The myth of the photo stated that as a politician, one way to secure approval and to be remembered by the constituents is to be like a common person doing daily, typical tasks of an ordinary citizen.

Then, the next photo signified the volunteerism of Filipino during a crisis. The photo labeled as ONP-03 describes people riding on a rubber boat. It has a denotation stating that eight people wearing face masks are riding on a rubber boat on a flooded, urban street where electric wires are loosely dangling. The PNP, BFP personnel, and civilians, whose half of the body is submerged in flood, support every side of the boat to prevent it from capsizing. The connotative meaning of the photo indicated that people on an overloaded rubber boat struggles for survival. The people helping them depicts volunteerism and unity. The photo conveys the message that nobody should be left behind and that people, no matter what position they have in society, are willing to help those in need. Also, people never forget to wear their face masks which shows that they still value their health and the health of others. The myth expressed the notion that helping people who are in need is typical to Filipinos, especially when natural disasters strike.

The next signifier labeled ONP-04 indicates a woman wearing a crown while waving, signified that beauty queens bring pride to the country and enjoyment to Filipinos. The denotation column stated that a woman in a red Filipiniana gown with a crown and a white sash on her shoulders which states, "Miss Universe," is waving her left hand while holding a red rose on her right hand. The smiling woman is wearing a face shield, and she is surrounded by colorful flowers. Further, the column for connotation expressed the idea that the smile on the woman's face behind the face shield represents Filipino's resiliency and positive outlook amidst the problems of the country. The rose she is holding, and the flowers surrounding her are related to the concept of femininity and graciousness. While wearing the silver crown on her head, she is waving towards an audience which expresses the idea that she appreciates and recognizes their support for her to get the coveted crown. Finally, the myth formed from this photo shows that a beauty pageant gives joy and excitement to Filipinos. A candidate with a crown radiates the spirit of hope and positivity to Filipinos.

Also, the photo ONP-05 wherein people are on the street with signage stating "Konting Tulong po sa mga Driver" signified the parent's struggle to feed their family. The third column is where the denotative meaning of the photo is discussed. The photo shows a woman on the street carrying her son. One man wearing a face mask extends his arm while holding an empty plastic gallon container. There is another man, wearing a checkered, sleeveless shirt, sitting on the floor of the jeepney. There are two signs in front of them, stating "Konting Tulong po sa mga Driver" and "No Parking". The connotative meaning of this photo is expressed on the fourth column wherein, based on the two men's appearance and posture, they are family men and must provide for the needs of their family. The man holding an empty plastic gallon container signified an act of asking for a small help from vehicles and passers-by, as evidenced by the sign written on cardboard in front of him. The other man in a sleeveless shirt resorted to sitting on the floor of the jeepney rather on the driver's seat, signifying that they cannot do their regular job because of the restrictions caused by the pandemic. The sullen-faced woman is casually standing on the side of the street while carrying her baby as if waiting for something. The myth indicated that people would do anything to provide food for the family, even to the point of begging.

24 Consortia Academia Publishing (A partner of Network of Professional Researchers and Educators) 
Safety and security must be upheld whenever and wherever. This is what the photo ONP-06 signified. The signifier entails a police assistance desk beside the beach. The denotation of the photo had described a man in the police assistance desk stationed beside the clear, blue beach with white sand. The help desk is located between two coconut trees. The atmosphere is bright. Further, the sunny and inviting ambiance of the beach depicts a feeling of calmness and freshness. The police assistance desk amid this serenity radiates a sense of security to the place. This is the connotation extracted from the photo. The myth is about knowing that wherever one goes, feeling safe and secured is important to enjoy a place truly.

As seen in ONP-07, in which women in pink uniforms wear face shields and face masks, it can be signified that teachers continue to provide education in alternative ways. The denotation, as reflected in the third column, described one woman in a pink uniform is looking at the other woman in a ponytail. The woman at the center is lifting a box. Other women in the background are talking. Moreover, the connotative meaning explained that these women in pink uniforms are teachers who are busy preparing for the packaging, sorting, and delivering of self-learning modules (SLM). The photo candidly describes the duty of teachers who are extra cautious in carrying out their tasks as front liners in education. The myth implied that education must continue despite pandemic.

Moving forward, the signifier ONP-08 discerns a woman and child taking a selfie in front of Basilika ng Nazareno. It signified that Filipinos are fond of taking pictures, especially on special occasions. The denotation for this photo described a smiling woman wearing a blue t-shirt raising her right hand holding a phone. The boy is holding her right wrist while looking at the same phone. A middle-aged man, wearing an orange polo shirt and looking sideways, is behind them. The building has a terrace where a woman takes down a red and yellow curtain along its fence. Jesus Christ statue is built on the wall of the building, and beside it is a signage.

Further, the connotative meaning for this explained that the red and yellow curtains being taken down at the background suggests a recently concluded celebration of the Traslacion of the Black Nazarene. The grinning mother, with his son taking pictures in front of the church, expresses their delight for the occasion. The myth of the photo articulated the notion that the Catholic church has many religious observances. In festivities and holidays, Catholics feel the joy and excitement for the event, and they do not forget to capture the moment by taking photos.

Additionally, the signifier ONP-09, which entails people with a cross marking on their foreheads are praying, had signified that Filipinos are prayerful. The photo can be described in a denotative level wherein a middle-aged woman wearing a blend of black and violet blouse is closing her eyes, opening her mouth, and lifting her hands. A woman in her 30s is wearing a checkered, long-sleeved shirt is next to her, who also lifts her hands and shuts her eyes. The woman on a red blazer is lifting her hands as well while looking above and opening her mouth. The woman beside her, wearing a black blouse, closes her eyes intently while lifting her hands. All of them have cross markings on their forehead. In this scene, it can be connoted that Filipinos express their faith by praying intently and singing passionately. With women closing their eyes, this suggests that they want to block out distractions and focus on their conversation with God. The cross of ashes on the forehead shows that it is the start of Lent, a 40-day period of penance for Christians around the world. The myth generated focused on the idea that Filipinos are known to be religious.

Also, the signifier labeled as ONP-10 exhibits a man wearing a white polo shirt feeding the elephant. It signified that government official is the initiator of good deeds. The denotation for this photo described the elephant extending its long trunk to the hand of a man in a white polo shirt who is Mayor Isko Moreno. Right outside the fence where the elephant is situated, a small crowd is wearing face masks and face shields. They are taking pictures and videos on the feeding activity of the man to the elephant.

Additionally, the connotative meaning of this photo concentrated on the man's message to take care of the animals. With the challenges we have because of pandemic, realizing the role of animals in the lives of humans is very important. The balance of nature should be restored and sustained. The people taking photos on the 
feeding activity represent an idea that this kind of activity must be replicated by other people. Its corresponding myth stated that a government official must be a role model for others.

Next, the signifier ONP-11 shows a man carrying an empty gallon container bottle while showing the cardboard with written words stating, "Mom \& Sir, Tulong po sa mga Driver ng Jeep. Salamat po." It signified those drivers are struggling to support their families in this time of pandemic. The denotation of the photo described a busy street wherein a man wearing a red cap, black face mask, face shield, and light blue shirt is extending an empty plastic gallon container on her right hand and holding the cardboard in his left hand. Behind him are other men doing the same thing as him. The connotation column further meant that people are begging for monetary help from the passing vehicles for their family's survival. As stated in the cardboard, it can be implied that they are drivers but cannot do their day job. This scene captures the perseverance and dedication of the providers of the family, who are usually the fathers, just to feed their family. Its myth talks about the idea that begging is not something that drivers usually do. But given the situation caused by the pandemic, they are desperate to do anything to feed their family. Fathers will find any possible ways just to provide food on the table.

The next signifier labeled ONP-12 about a baby wrapped in white linen wearing a face shield signified that the newborn babies must be protected against the virus. The denotation for this photo focused on the description of the crying newborn baby wearing a blue face shield and tightly wrapped in white linen from the neck down to the foot. The baby is placed on a bed with orange linen carrying a logo of the University of Santo Tomas Hospital inscribed on it. Also, it connoted that the crying baby symbolizes new life and new hope. The white linen wrapped around him describes the purity and innocence of the baby amidst the problems, like pandemic, we are facing right now. With the face shield on, it conveys a message that newborns must be taken care of as they are vulnerable to the virus. The myth for this photo has the idea that pandemic affects all ages. Protecting vulnerable babies against the virus is important.

In the proceeding signifier labeled as ONP-13, which shows two personalities wearing face masks, it signified that those celebrities and politicians may share the same perspectives about various things. The denotation for the photo described Senator Lito Lapid on the left side wearing a navy-blue blazer on top of a white collared button-down shirt with his face mask on. On the right side, with his face mask on, is Coco Martin, who is sporting a black, zip-up jacket with a white polo shirt underneath. They are both walking in the same direction. The connotative meaning of this photo centered on the idea that the two personalities in two contrasting fields, politics, and showbiz industry, have come together. This signifies that anyone can unite regardless of one's position in society. With their face masks on, it shows their obedience to the set protocols. Walking in the same direction conveys the idea that both of them are like-minded and have similar viewpoints regarding issues in society. This photo's myth implied that agreement and harmony are possible even though there is a big difference between politics and showbiz industry.

For the signifier ONP-14, which shows a woman holding plastic bags while looking at the soldier, signified that following the rules and regulations is strengthened if there are persons-in-authority nearby. The denotative meaning described the scene wherein beside the road, a woman is wearing a red shirt, patterned shorts, face mask, and an ID with a sling hanging on her neck while looking at the soldier in full gear. She is holding two plastic bags with disposable lunch packs inside. Behind her is another woman who is also looking at the soldier wearing a blue sleeveless shirt and black pedal pants. Further, the photo connoted that the two women holding plastic bags depict the typical everyday image of Filipinos doing errands and buying food for the family. However, wearing a face mask and an ID with a sling around their necks portrays an idea that they need to comply and follow first the regulations set by the government to perform their normal everyday tasks. The soldier's presence is a reminder to the people to obey and uphold the rules and regulations. The myth for the photo centered on the notion that Filipinos are following rules, especially if there are persons-in-authority keeping an eye on them. 
Lastly, the signifier ONP-15 exhibiting a man wearing a face mask and looking at the signage that states "No Face Mask, No Entry" signified that signages remind everyone what to do and follow. Also, it denotes that man wearing a black t-shirt with a blue sling on his neck is reading the signposted on the wall. In front of him is a woman with long hair wearing a black t-shirt entering the door. The sign beside the door, posted on the wall, states, "No Face Mask, No Entry." The photo connoted that the woman on the door complied with the requirement posted on the wall that permits her to enter the door without any problem. The man behind her is reading the sign reminding himself of the protocols to follow. This picture captures the idea that people must obey what the government's rules and regulations are telling them to do. The myth described posting signages of reminders on the wall is an important measure for any establishment to remind their employees of the rules and regulations they need to follow.

\subsection{Research Question No. 2. How does students' understanding of online news photographs affect their \\ personal viewpoints regarding issues in society?}

The subsequent questions were asked to find out how students' understanding of online news photographs affects their personal viewpoints regarding issues in society. What social issues are found in these news photographs? What messages are conveyed by these news photographs? What emotions did you feel upon seeing these photos? How do these emotions affect your perception of the current situation in the Philippines? What do you suggest to the government or any person in authority to change or improve these concerns? What are the things that you can do, as a student, to contribute to your community? Data were collected and analyzed using the above questions to determine these six essential themes, as shown in Table 3. These are Personal Concerns, Public Awareness, Clarity of Message, Stewards of the Importance of News, Sociological Imagination, Civic Action.

Table 3

Themes and Core Ideas of How Students' Understanding on Online News Photographs affect their Personal Viewpoints regarding Issues in Society

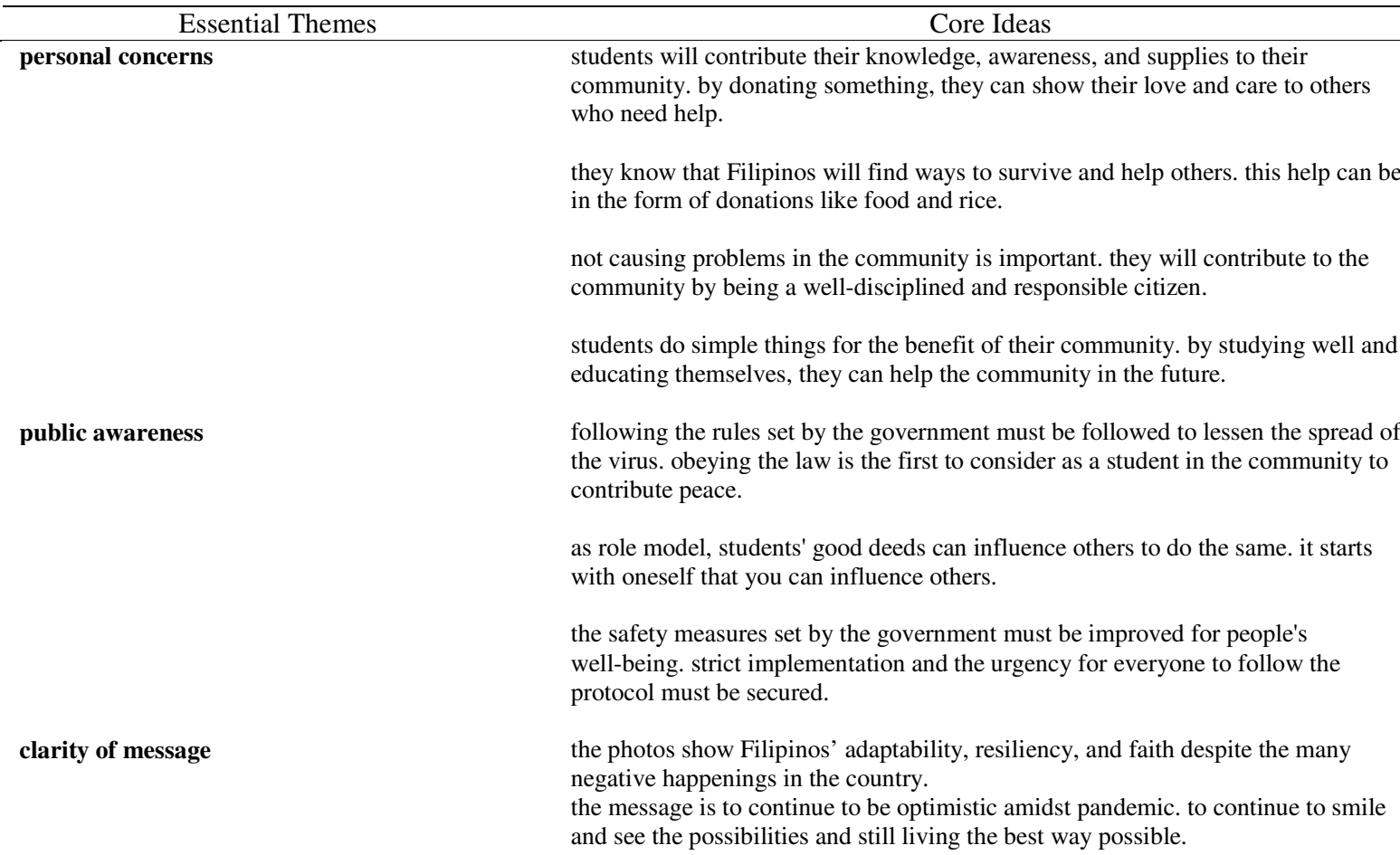

the photos show that Filipinos never give up no matter what problem may come in their way. in general, they are resilient and will survive no matter what. 
sociological imagination

civic action students will share their learnings with others regarding issues in society, especially during pandemic. they see that many people will read the information online.

students see social media as a powerful tool to persuade others to help. by posting on Facebook and twitter regarding these important matters, they can raise awareness of the current issues.

generally, students feel sad about the happenings in the country, primarily because of the challenges brought about by pandemic and the calamities faced by Filipinos.

students are hopeful that one day Filipinos will overcome the problems today as a country through people's volunteerism and the government's support.

students are optimistic that there will be a positive outcome sooner, especially that being helpful is innate to Filipinos.

students will join organizations in their barangays to contribute to the community. engaging themselves in various bayanihan programs can help a lot of people.

students will join barangay activities like tree planting and other related activities that could help other people.

being a volunteer in the barangay is a big help to expedite the tasks. this is to give an extra workforce to help the local government in implementing its programs and various civic activities.

Personal Concerns - Online news informs viewers of the latest events in the country. It helps them understand better the happenings in other places. When certain news is paired with photographs, meaning is exemplified. Thus, they can further relate and react to it. Viewers tend to sympathize with what is on a photo. Often, they subconsciously compare, relate, or associate the news to their own situation as citizens in the country. Thus, personal concerns form in the mind of the viewers. From a society's point of view, personal concerns happen when one is thinking of what they can do to contribute to the betterment of an individual or group or alleviate the current condition of the community regardless of the intensity of its impact. It gives one the sense of urgency to act about something they care about. In relation to this, Grasya stated that:

"I would contribute my knowledge, awareness, and supplies to my community to help them stay safe as well as other people. To show my love and care sa ilaha ning donate ko ug something nga makatabang sa ilaha like foods, rice nga makahatag sa ilaha ug kuan sa pang adlaw-adlaw ma'am.” (IDI-O1)

(I would contribute my knowledge, awareness, and supplies to my community to help them stay safe as well as other people. To show my love and care to them, I have donated something to help them, like food and rice, to get them through the day.)

The statement above was supported by Blietzkrieg when he also mentioned during the interview that:

"The things I can only contribute to my community is to be a responsible nga mamamayan ma'am and to be disiplinado. Pagbuhat sa mga simple nga butang, musunod sa protocol, ingon ana ma'am.” (IDI-05)

(The things I can only contribute to my community are to be a responsible citizen and to be disciplined. Do simple things, like following the protocols, just like that, ma'am.)

As a student, they have thought of simple ways to contribute to society and show their personal concerns. Further, such responses were supported by Flower who emphasized the value of kindness towards other people despite the difficulty of the current situation, she mentioned that: 
“Ang panginabuhi sa Filipino kay lisod jud pero ang Filipino kay nagkuan jud sila para makasurvive ug makatabang sa isa't isa. Unya kun naa pod koy makuan nga mga lumad ma'am kay mubaba man gyud na sila sa barangay kay I will help them by giving them clothes pang depensa nila in anyways nga mahitabo." (IDI-03)

(The Filipino living is really difficult, but the Filipinos find ways to survive and help each other. Then, if there are indigenous people, for sure they will come down from the mountains to the barangay, I will help them by giving them clothes to defend themselves to whatever may happen.)

Johan confessed that he has limited resources to help others. However, in his small ways, he gave his views on how he can contribute as a student, he shared that:

"Para sa akoa Ma'am is as a student, limited ra man jud mahimo pa nako run. So basic lang, mag start lang sa gagmayng butang, Ma'am, by obeying the rules nga gi-implement karon. And also Ma'am dili sad mawala ang prayers Ma'am na mag balik na ang tanan sa normal and wala nay mag suffer.” (FGD-02)

(For me, ma'am, as a student, I have limitations in what I can do. So just the basic, start with little thing by obeying the rules implemented today. And also, do not forget prayers that everything will go back to normal and that no one will suffer.)

As a student, concern for others can be realized by doing simple things. This modest act of helping was specified by Red when she stated that:

"Para sa akoa ma'am prayers that's all I can do as a student and as a Filipino. Siguro mag donate ka atong mga naapektohan sa bagyo ug magspread ug awareness about sa COVID-19." (IDI-02)

(For me, praying is all I can do as a student and as a Filipino. Perhaps, I will donate to those who were affected by the typhoon and spread awareness about COVID-19.)

Yowkai expressed her insights on the idea that youth is the hope of our nation. She revealed in the interview how important education is for students to contribute to society in the future.

“As a student, dili lang jud ako ma'am, unta ang uban pod, mas eeducate pa jud ang atong mga kaugalingon para kami ma'am mu-stand as one of the future that the society needs today or forward. Mag study gyud arun maabot namo among future jobs, arun makatabang mi sa society ma'am.” (IDI-07)

(As a student, it should not only be me, I hope others too will further educate ourselves because we are the ones that the future needs today and in the future. We must study hard to achieve our future jobs, to contribute to society.)

On the other hand, Flower never forgot the support of the government and how to be a role model in the community, she mentioned that:

“Ang government officials kay nangita sila'g mga ways para sa kaayuhan sa tanan. As a student, I won't be the headache of my family and the officials in our barangay. Mugawas ko nga naga-face mask ug dili ko musabay sa mga tapok-tapok." (IDI-03)

(The government officials find ways for the benefit of everyone. As a student, I won't be the headache of my family and the officials in our barangay. I will go outside wearing a face mask, and I will not go to gatherings.)

Public Awareness - Public awareness has been emphasized by the students for it affects their viewpoints on 
issues in society. The widespread circulation of these online news photographs on various websites and social media platforms serves as an important tool to inform them of the current situations in the country. In understanding the meaning of these photos, students build a sense of urgency to spread awareness to other people, to help them understand the situation and what must be done to improve each and everyone's life amidst crisis.

On the other hand, seeing the reality through photographs, students had been more conscientious on looking into the governments' duties and responsibilities for the welfare of the general public. Hence, students had formed their suggestions and recommendations for the government to improve its commitment to its constituents. They had mentioned the significance of following the rules and regulations as an essential thing for the public to do this pandemic. During the in-depth interview, Tricky said that:

"Kailangan jud nato magfollow sa mga protocol sa government kay para dili na mas mulala pa ang pagspread sa coronavirus diri sa atong country.” (IDI-06)

(We really need to follow the protocols of the government to avoid worsening the spread of the coronavirus in our country.)

The same idea was expressed by Yowkai. She revealed the urgency of following the laws to avoid loss of life.

"Obeying the law is the first to consider as a student of the community to contribute peace within the society. Then it is needed to implement a strict ordinance to avoid loss of life." (IDI-07)

These answers were further affirmed by Aphrodite during the focus group discussion when she stated that:

"Obey lang jud ta sa mga rules na ginapa-implement sa atong gobyerno kay para man gihapon na sa atoa, para sa atoang safety.” (FGD-03)

(Let us just follow the rules implemented by the government because it is for us, for our safety.)

Sunset added to this idea, he mentioned that:

"We must follow protocols. Quarantine protocols, lockdown protocols, and any other protocols na ginapa implement sa atoang government." (FGD-05)

(We must follow protocols. Quarantine protocols, lockdown protocols, and any other protocols implemented by our government.)

Blckmale had asserted that one could not effectively raise public awareness without being a role model first for oneself and to other people. He shared that:

"We can be a catalyst of change, and we can be a good example to them, murag everything starts with yourself. You can show them what are things you must do by doing things on your own, murag ing ana gani Ma'am. Starting from yourself that can be an influence to others." $(F G D-01)$

(We can be a catalyst of change. We can be a good example to them; it seems like everything starts with yourself. You can show them what are the things you must do by doing things on your own. Starting with yourself, you can be an influence on others.)

Additionally, in analyzing the online news photographs, students' sensibility on social issues was heightened, making them share their knowledge and suggestions for the betterment of the country. Tricky revealed the importance of social media and proposed that:

30 Consortia Academia Publishing (A partner of Network of Professional Researchers and Educators) 


\begin{abstract}
"Dapat mag-ano pod ang government pajud ug mga murag para mainform gani ang tanan kanang kini ang dapat buhaton, Kailangan ni sila ipreserve nga mga animals para kay ingon ani ang matabang nila diri. Gamiton nila ang social media platform kay dako man jud ug impact ang social media para sa pag spread ug mga information.” (IDI-06)
\end{abstract}

(The government should have better information dissemination so that the people will be able to know the things that they should do. Animals should be preserved because they all serve a purpose. Social media platforms should be used by them (government) because it has a wider scope in spreading information.)

By intensifying her public awareness, Eleven directly suggested that improvement must be made by the government. But to materialize a real and lasting change, everyone must work together for a common goal. Particularly, she advocated that:

"I think the government should improve the safety of people against COVID and improve the rules and responsibilities provide for people's well-being. Although government alone cannot solve a society's biggest problems but through compassion, we could have a better place to live." (FGD-07)

Sunset, who served as a volunteer in their barangay during a pandemic, has seen the problem and cited that the local government must be empowered to fully realize the improvement and change that everyone desires to achieve.

"I suggest Ma'am na ang executive departments through DILG or Department of Local Government na i-empower gani ang mga local government units kay ang local na panggamhanan man gyud ang pinaka una na muhatag ug aksyon gyud Ma'am sa kung unsa man ang problema sa ilahang lugar Ma'am kay ang uban man gud na mga LGU Ma'am kay sloppy kaayo, bali hinay kaayo ilang pagtagad sa mga problems. So dapat i-empower pa gyud ang LGU Ma'am para mas paspas ug mas dali ang ilahang mga aksyon nga buhaton Ma'am." (FGD-05)

(I suggest that the executive department through the Department of Local Government (DILG) should empower the local government units. This is because the local government units are the first ones to execute actions whenever a problem arises in their locality. Some localities are so sloppy; they are so slow in addressing the problems. That is why LGUs should be empowered so that there will be more direct and speedy actions to the problems in their society.)

Just like Sunset, Johan added the role of local government in addressing the root cause of the problem. Being aware of the intensity of the problem, he shared his idea on the vital role of the local government in addressing public concerns.

“Then also, mag start sa local kay murag higpitan pa jud ang mga, pagtuunan ug pansin ang mga problema diria just like sa pandemic nga mag start ta sa gamay nga butang ug for example sa local murag higpitan nato diraa na part.” (FGD-02)

(Also, the local government should have a firm focus on the problems like pandemic. We should start on the small things, for example, on the local scenes where we should have a more solid and strict focus on the local problems.)

Clarity of Message - With much news in our society, tremendous amounts of information were fed to us on various platforms, especially online. Due to this, confusion may arise on what to believe. Photographs will serve as evidence that something really happens. Because of the influence that a photo conveyed, it eradicates the sense of doubt and directs the viewers on its intended meaning. Photographs can transmit clearer messages to the viewers. It sends a better message, if not equally, with that of the articles. Through the online news photographs 
that the audience perceives, they could form their own understanding of the important matters happening around them. Hence, this photograph sends a much clearer and stronger message which is very significant in shaping their sensibility as Filipino citizens. Grasya shared her general insights upon seeing the given online news photographs.

These news photographs have a significant impact and message on every one of us. That no matter what calamity we're facing right now, we are still praying, hoping to strengthen our faith. Helping each other no matter how hard the situation." (IDI-O1)

Additionally, Dolores also shared ideas, describing the overall values Filipinos possessed during these trying times.

"Ang mga message na akoang na-incorporate sa photos Ma'am kay adaptability, resiliency, and faith sa mga Filipinos Ma'am amidst, despite sa mga nahitabo Ma'am.” (FGD-04)

(The messages I have incorporated from the photos are adaptability, resiliency, and faith of the Filipinos despite the happenings.)

Johan has the same perspective as Dolores. He, too, has seen the struggles as reflected by the online news photographs. But with all these, Filipinos generally were able to rise from these problems, and they will never give up no matter what. He shared during the focus group that:

"Para sa akoa Ma'am, ang messages that conveyed is about the resilience sa mga Filipinos gihapon Ma'am on how they managed to cope sa ilahang struggle Ma'am by having faith, determination, cooperation, comprehend, and understand each other Ma'am.” (FGD-02)

(For me, the messages conveyed are about the resilience of the Filipinos on how they managed to cope with their struggles by having faith, determination, cooperation to comprehend and understand each other.)

Blckmale revealed the optimism he felt upon viewing the photos. Amidst the many negativities surrounding us, he was able to see the light at the end of the tunnel. Life may be hard, especially today, but for the participant, he believed that Filipinos have something to smile about.

"Ang message is to continue our life Ma'am ba even in the midst of pandemic we can still see the possibilities to continue to smile, and to look for something that will help ourselves and our lifestyle and our family to feel the same way bisan pag dili na sya the same sa old normal, new normal na sya murag we're still living in the best way we can murag ing ana, Ma'am." (FGD-01)

(The message is to continue our life even amid pandemic. We can still see the possibilities to continue to smile and look for something that will help ourselves and our lifestyle, and our family feels the same way even it is not the same anymore with the old normal. We are in new normal; we are still living the best way we can.)

Sagittarie discovered the resiliency of Filipinos in all aspects of life, as shown in the photos. She shared how they never surrender on whatever problems that may come in their way. She told the group that:

"Para sa akoa Ma'am kay ang message kay nag conveyed that Filipinos are always looking for possible ways to survive religiously, economically, and politically. Siguro ang maingon nako sa mga Filipinos kay basin pag unsa na ilang gi-atubang Ma'am kay wala jud sila ni give-up." (FGD-06)

(For me, the message conveyed is that Filipinos are always looking for possible ways to survive 
Looking at the bigger picture: A semiotic analysis on online news photographs

religiously, economically, and politically. Maybe, I can say to Filipinos that even if they are facing different challenges, they will never give up.)

Stewards of the Importance of News - As students formed various meanings of the online photographs shown to them, they instinctively understood the significant power of raising awareness and spreading the news to all the people. Stewardships refer to the careful and responsible management of something. Through the photos they had seen, news and how it is delivered and conveyed to the audience should be taken into consideration. Relaying the important happenings that need attention and conveying the latest and accurate news and information serve as an important role as stewards of the importance of news. More specifically, students have sensed the accountability and responsibility in transmitting accurate news in their social media feeds. Raising public awareness and updating their friends and followers of the government's progress is vital in creating a cognizant society. Tricky shared her way as a steward of news.

"I-spread pod nako akong learnings ma'am ishare pod sa uban para makahibalo pod sila ana or ipost sa social media para daghan pod ang makahibalo about ana nga information.” (IDI-06)

(I will share my learnings with others so that they will know about our current issues, or I will post on social media platforms so that many people will know about the information.)

This statement was supported by Red when she mentioned in the in-depth interview that:

"Magspread ug awareness about sa COVID-19 dako na na siya nga tabang para sa karun nga issue.” (IDI-02)

(Spreading awareness about COVID-19 is already a big help on the current issues (we are facing)).

Also, Blckmale suggested finding easier ways to get easier access to news and information. This is to help better the citizen in preparing themselves for the worse to come.

"Murag ang akong ma-suggest lang sa ilaha is think of something ug murag pamaagi mas naay dali nila ma-raise ang awareness sa mga tao ba in terms of the things to do, murag prepared, murag kailangan pa nato i-prepare ang atong mga kaugalingon.” (FGD-01)

(My suggestion for them (the government) is to think of something, an easier way to raise awareness to the people regarding the things to do and prepare. Maybe, we need to prepare ourselves more.)

On the other hand, students felt responsible for spreading the news online, which is the most convenient way to spread information. Through their social media posts, they can help the community in their own little ways. Sagittarie said that:

"We have different social media platforms so we can raise awareness there sa Facebook, especially sa Twitter Ma'am. We can raise awareness there Ma'am para ma-aware pud ang atong mga uban Filipino Ma'am para kung unsa nay nahitabo karon ing-ana Ma'am." (FGD-06)

(We have different social media platforms, so we can raise awareness there like Facebook, especially Twitter. We can raise awareness there so that our fellowmen will be aware of the happenings today.)

Dolores asserted the idea of using social media to raise awareness. She shared to the group how, as a student, she can be of help to society while at home.

“As a student Ma'am tapos kanang naa lang sa balay permaninti, gamiton ang social media ba 
as advantage Ma'am para manghikayat Ma'am na kanang mutabang." (FGD-04)

(As a student who always stays at home, I will use social media as an advantage to persuade others to help.)

Sociological Imagination - Seeing the news photographs provides a sociological imagination to the students. The term sociological imagination refers to the concept of shifting your perspective away from oneself and looking at things more broadly. Specifically, photos have provided a way for students to think not just for their individual welfare but for society. This encourages them to sympathize, understand and act on a broader scale, thus impacting society in one way or another. Through sociological imagination, students formed various reactions and feelings towards the issues in society. This allows them to look into the issues with fresher and more critical eyes. In realizing the messages conveyed by the photos, Participant Red had expressed her sadness regarding issues in society. However, she also revealed her optimism towards these problems. In the interview, she asserted that:

"Sad syempre pero dili pasabot nga mawal-an nalang pod kag hope na murag wala dili na makabangon ang Pilipinas. Pero ano, we maybe look hopeless because of all what's happening today pero karun ra na. We will rise soon and get over with it.” (IDI-02)

(I'm sad, of course, but it does not mean that you will lose hope that the Philippines will not rise again. We may look hopeless because of all the happenings today, but this is only for now. We will rise soon and get over with it.)

This kind of feeling was attested during the focus group discussion when Aphrodite declared her feelings on the happenings in the country, especially with the pandemic and typhoon. She shared that:

“Ang nabati nako sa mga pictures Ma'am is sad ko Ma'am kay though kitang tanan naka sinati ug kitang tanan aning pandemic naa japoy uban lugar specially didto sa Luzon na naa na gani Covid, na-igo pa jud sila ug typhoon na kusog kayo which is nasundan jud ug Rolly ug Ulysses. Sad pud ko Ma'am kay because isa sa mga apektado aning Covid kay ang mga newborn babies so, dapat ampingan jud sila kay dili nato makita jud ang kalaban nato which is ang virus." (FGD-03)

(What I felt from the picture is sadness. Though all of us are experiencing this pandemic, there are still places, especially in Luzon, affected by COVID-19 and were also struck by strong typhoons like Rolly and Ulysses. I'm also sad because newborn babies are affected by COVID-19, so we have to take good care of them because our enemy cannot be seen by our naked eyes, which is the virus.)

Amidst all the challenges, participants were also hopeful. For Sunset, all of the problems will be overcome by Filipinos. Also, he shared to the group the value of helpfulness and how important it is in solving or alleviating problems in the country.

"I feel ano Ma'am hopeful ani nga mga pictures Ma'am kay amidst of pandemic Ma'am hopeful ko na maka-recover tanan. Ma-overcome ra ni sa mga atong fellow Filipino citizen. So even though nga we faced a lot of struggles, a lot of calamities, unsa pa na atong kanang sagobangon diraa Ma'am, we Filipinos are strong and we can overcome all of this Ma'am. I still feel ano Ma'am hopeful, kay aside from unity among Filipino people, kay we have our government to provide aid sa atoa. Akong perception gihapon Ma'am is still positive kay ang pagtinabangay gyud ang permi naa jud sa atoa mga Filipinos Ma'am. So, they won't give up gyud maski pag unsa pa na kalisod ang problema." (FGD-05)

(I feel hopeful about these pictures because, amidst the pandemic, I am hopeful that everybody 
will recover. Fellow Filipino citizens will overcome this. So, even though we face many struggles, a lot of calamities, whatever may come in our ways, we Filipinos are strong, and we can overcome all of this. I still feel hopeful because aside from the unity among the Filipino people, we have our government to provide aid for us. My perception is still positive because the act of helping one another is already inherent to us Filipinos. So, they would never give up, no matter how hard the problem might be.)

Lastly, these statements were supported by one of the participants as he discussed his perspectives regarding issues in society. Online news photographs had paved the way for him to understand better the struggles and problems and, more so, the optimism and the country's brighter future.

"Seeing people, how they help each other and the people how they unite themselves just to help each other Ma'am murag naa gihapoy optimism nga to look for the beauty in it, for the silver lining char, bitaw murag kanang nakita gihapon na murag ang pag tan-aw sa Philippines even though how many times we struggle, how many conflicts we faced, were still optimistic. Akong panan-aw napud sa atong country murag bisan unsa pa kadako sa problems, the people will always solve the problem. The people will always find solution for the problems. So, I'm optimistic na positive jud ang atong kapadulngan sooner or later maybe puhon puhon jud." (FGD-01)

(Seeing people, how they help each other, and how they unite themselves just to help each other, there is still optimism, which is to look into the beauty in it, the silver lining. I still see that Philippines, even though how many times we struggle, how many conflicts we faced, we are still optimistic. My view about our country is even how big our problems are, the people will always solve the problem. The people will always find a solution for the problems. So, I'm optimistic that we will have a positive outcome sooner or later, hopefully.)

Civic Action - Engaging in various activities in their barangays and community is one of the students' realizations that arises upon seeing the photographs. Recognizing the problem is one thing and taking contributory actions is another. As a student, they have understood the struggles in the country, and this prompts them to make some actions to contribute to their community even in their own small ways. Civic actions relate to one's engagement in any social activities to make a difference in society. This involves volunteering, joining group programs and activities, and tree planting, and many others. Students' understanding of the meaning of online news photographs has changed their perspectives of the world around them. They have devised ways to participate and involve themselves in varied civic activities. As a student, Jennsie shared this:

"For me ma'am ang best jud nga maano sa estudyante matabang sa community is pagskwela ug tarong then muapil sa mga peers or organization sa ilang barangay or something mga SK.” (IDI-04)

(For me, the best way for students to help the community is to study well and join peer groups or organizations in their barangay or Sangguniang Kabataan.)

This kind of civic engagement was further emphasized by Aphrodite when she shared this one specific barangay activity to help protect the environment. She uttered the importance of tree planting activity.

"Ang akong ma-contribute is kanang mag-apil ug mga activities diri sa atong barangay which is applicable sa atoa example ani kay tree planting, need jud kaayo nato na sya kay karon wa ta kabalo kung anytime muabot nga bagyo, at least naa tay mga trees na mu protekta sa atoa mao na sya isa sa activities sa barangay." (FGD-03)

(What I can contribute is to join activities in our barangay that are applicable to us, like tree planting. We really need it because when a typhoon hits, at least we have trees to protect us. That 
is one of the activities in the barangay.)

Additionally, one participant also attested to the importance of being a volunteer in the barangay. As a student, it is important for him to involve himself in some barangay works. Sunset shared that:

"If gusto Ma'am like me, you can be a volunteer in your barangay para makatabang or maka hatag ug extra na manpower para mas dali ang mga buhaton." (FGD-05)

(If one may like, you can be a volunteer in your barangay like me to help or give extra manpower to expedite the tasks.)

Sagittarie intended to engage herself in barangay activities. Seeing the need of her community, she uttered this plan of action:

"Maybe I could take part sa mga activities which provide help to those in need Ma'am. Ang sa among barangay Ma'am is mag distribute ug mga goods gud Ma'am mga ing-ana Ma'am." (FGD-06)

(Maybe, I could take part to activities which can provide help to those in need. Like in our barangay, the distribution of goods, something like that.)

Lastly, Eleven highlighted the value that she embodies to contribute to the community. This value is paired with action through participating in the bayanihan program.

"As a student Ma'am, I think what I can contribute to our community is my active cooperation and kindness. I think, indeed, lots of people Ma'am are in need and by engaging myself in different bayanihan program." (FGD-07)

4.5 Research Question No. 3. How do the semiotic features of online news photographs aid in the visual literacy of students?

The following questions were asked to determine how the semiotic features on online news photographs aid students' visual literacy. What are the details on the online news photographs caught your attention the most? What makes the news photographs effective in sending to the audience its intended meaning? What strategies are used in the photos to convey meaning? How important are the details in the photos in interpreting its intended meaning? From the data collected using the above questions, three essential themes were formulated from the responses, as shown in Table 4. These are Offer Visual Metalanguage, Express Emotions, and Convey Messages.

Offer Visual Metalanguage - Visual metalanguage enables students to comprehend and compose meaning out from the photographs given and relate it to the society they are in. For the students, photo has the ability to tell a story without using any words or texts. The meaning is formed through the photo's details like the subject's actions, facial expressions, and body gestures. With this, they can be informed of the actual happenings in society immediately. Comprehension of various social issues was made easier if the news is being supplemented by photos. Photographs, when analyzed, can be a great tool for understanding the world we are living in. It sends forth a message, and it touches viewers' emotions and sensibilities. Through these, they can formulate an in-depth understanding of the situation. Indeed, for students, photos offer an avenue for easier access to information, especially that they are undoubtedly visual learners. Moreover, through the details of the photo, students were able to make their own interpretations and meaning out of it. The details on an image carry a meaningful message for the viewers. Thus, without caption or even by not reading the entire article, creating meaning can still be made possible.

Visual metalanguage enables students to understand deeply the news and Tricky has something to say on the importance of the details of the photos in meaning-making. She said in the in-depth interview that: 
“Importante ang iyang mga details ma'am kay para makasabot pod ang mga tao ma'am kung unsa pod ang iyang ginahatod nga message through ato nga picture ug mas makasabot pod ang tao kun unsa juy unsay mga balita nga pod pasabot niya.” (IDI-06)

(Details are very important so that people will understand what message those pictures are trying to convey, and people will have a better grasp of the news.)

\section{Table 4}

Themes and Core Ideas of How the Semiotic Features on Online News Photographs aid on the Visual Literacy of Students

\begin{tabular}{|c|c|}
\hline Essential Themes & Core Ideas \\
\hline \multirow[t]{4}{*}{ Offer Visual Metalanguage } & $\begin{array}{l}\text { The photos reflect the two worlds in our society- the situation of the rich vs. the poor. } \\
\text { The photos show the dualism of life in the country. It conveys the positive stories and } \\
\text { negative stories or both. }\end{array}$ \\
\hline & $\begin{array}{l}\text { Details in the photographs are vital in understanding its message easily by the } \\
\text { viewers. Through these details, they can better grasp the content of the news. }\end{array}$ \\
\hline & $\begin{array}{l}\text { Photographs can convey abstracts and concepts through facial expressions. Through } \\
\text { the details, the viewers can empathize with the positive or negative emotions evoked } \\
\text { by the photos. }\end{array}$ \\
\hline & $\begin{array}{l}\text { Details in the photo help in understanding the whole story. There is no need to read } \\
\text { the entire article because the photo speaks for itself. }\end{array}$ \\
\hline \multirow[t]{4}{*}{ Express Emotions } & The details are where one can understand the photograph even better. \\
\hline & $\begin{array}{l}\text { The emotions in the photographs effectively help send its meaning to the viewers. It } \\
\text { accurately depicts the situation in our society. }\end{array}$ \\
\hline & $\begin{array}{l}\text { The emotions paired with physical actions can convey a message immediately. Even } \\
\text { without analyzing the photo intensively, it can already send a message. }\end{array}$ \\
\hline & $\begin{array}{l}\text { It evokes emotions because it tells a contrasting story of the wealthy and } \\
\text { impoverished. }\end{array}$ \\
\hline \multirow[t]{4}{*}{ Convey Message } & $\begin{array}{l}\text { Emotions of the people in the photograph and the timing of the photographer help in } \\
\text { conveying the message. }\end{array}$ \\
\hline & $\begin{array}{l}\text { Photos are effective in conveying its intended meaning instead of reading the whole } \\
\text { article. It's easier and convenient for the viewers to realize the message of the news } \\
\text { by looking into the photos first. }\end{array}$ \\
\hline & $\begin{array}{l}\text { Photos speak for themselves without additional information stated. The message } \\
\text { comes across to the viewers without reading its details or captions. }\end{array}$ \\
\hline & $\begin{array}{l}\text { Photos are evidence that something really happens, and it is a way to inform the rest } \\
\text { of the citizens that people are suffering. }\end{array}$ \\
\hline
\end{tabular}

Additionally, this statement was affirmed by Sagittarie. She has shared to the group that:

"More details in every photo make the reader or viewer understand the whole story even in the photograph itself.” (FGD-06)

Moreover, if, for Tricky and Sagittarie, details are important in establishing the grasp of the news, then Jennsie also revealed that inaccuracy of the details could make or break the intended meaning of the photos. Hence, visual metalanguage enables a viewer to be critical and scrupulous in understanding the meaning out of a photo. She uttered that:

“Ang details man gud sa picture ma'am dara mag-gikan ang pagconvey or pagsabot sa mga tao 
ma'am or sa mga readers. So, kun naa may mali diri ma'am or sipyat sa picture naay possibility nga misunderstand or ma misinterpret po sa readers, ma'am." (IDI-04)

(The details are where one can get the understanding from the picture. So, if there is an error or mistake on the picture, there is a possibility that it will be misunderstood or be misinterpreted by the readers.)

On the other hand, Blckmale shared that the given photos reveal two contrasting situations in our society. It tells a story of juxtaposition. In his interpretation of the photos, he shared that:

"Na caught jud akong attention is naay two different worlds or two different stories ang iyang gina try ug convey. Mura syag juxtaposition Ma'am ba. Mura syag nagahatag mga opposite sides. Mura syag neutral Ma'am ba nitan aw sya sa positive, negative or sa both stories sa ing ani na tao." (FGD-01)

(What really caught my attention is there are two different worlds or two different stories that those pictures are trying to convey. It is like a juxtaposition. It is like giving the opposite sides. It is like neutral, looking into the positive, negative, or both stories.)

It is also important to note that photos help portray the viewer's abstract concepts. Through the details of the photos, the students can have an idea of the accurate emotions that it is trying to evoke in the viewers. Aphrodite uttered that:
"Importante ang mga details Ma'am sa each photo Ma'am kay pictures have the ability to convey abstract and concepts Ma'am such as facial expressions Ma'am. So sa pagpicture ani, dili lang ang sitwasyon ang kuhaan nato ug detail pati ang mga facial expressions ug emotions sa mga tao. Kung sa kana nga sitwasyon unsa ilang gibati, nalipay ba sila, kaguol ug mga kakapoy nga ilang na agian Ma'am." (FGD-03)
(Details on each of the photos are important because pictures can convey abstract and concepts such as facial expressions. So, in taking this picture, it is not only out of the presented situation that we can get detail but also the facial expressions and emotions of the people, what specific feeling they felt in that particular situation. They may be feeling happy, sad or tired.)

Express Emotions - During the interview and group discussions, it was revealed that photos evoke emotions in the students. Since photos depict the real situations in society, this results in sympathy and various feelings. Through facial expressions present in the photo, emotions were conveyed, thus, exemplifying its meaning. Further, this generated theme also describes that through the actions of the people in the photos, meaning is formed by the students, and it helps them understand better the story that the photo wanted to portray. Notably, during the interview, Yowkai expressed how emotions help her understand its intended meaning.

"The emotions in these photographs help send effective meaning through their actions. Ang photo kay nagpakita gyud ug truthful gyud nga environment. Ma spread gyud nila kun unsa ang nahitabo sa atong society ma'am." (IDI-07)

(The emotions in these photographs help send effective meaning through their actions. The photo reflects a truthful scenario. Photos can spread awareness of the happenings in our society.)

Also, Sunset has the same notion regarding the statement of Yowkai. In addition to actions, for him, the eyes also help in interpreting the story of the photographs. He elaborated that:

"Effective sya Ma'am kay tungod sa emotions sa nawng na makita sa pictures Ma'am. Then, sa kadtong mga tao na nag face mask Ma'am sa ilang mga mata pud Ma'am. So, I think through emotions nga makita sa pictures, through physical actions na makita sa pictures, maka convey 
Looking at the bigger picture: A semiotic analysis on online news photographs

na daan sya ug message maskin pag tan awon pa lang nimo, wala pa nimo gi fully interpret ug maayo ang picture Ma'am.” (FGD-05)

(It is effective because of the emotions from the faces seen in the pictures. Then, for those people who are wearing a face mask, their eyes convey emotions. So, I think through emotions, through physical actions, it can already convey a message even in just a quick glance, even though you did not thoroughly and fully interpret the picture in the first place.)

Further, Dolores had cited the photographer's strategy to evoke emotions in the viewers. By portraying two different worlds in one photo, it helps students to sympathize and understand the story.

“Ang akoang own understanding Ma'am kay ang strategy na gigamit sa photographer Ma'am kay murag nag pakita gud sya ug kanang two different worlds Ma'am ba. Pareha aning first picture Ma'am kanang nakasakay sila sa car nya ang uban kay naa sa ubos." (FGD-04)

(On my own understanding, the strategy used by the photographer is he is showing two different worlds. Like this first picture, they are riding the cart while others are on the side.)

The statement was also mentioned by Sagittarie, she stated during group discussion that:

"Ang akoa Ma'am kay ang gibasehan man gud Ma'am ba kay ang first pic Ma'am then murag syag naa guy story Ma'am. And para sa ako gigamit niya ang rich ug ang poor.” (FGD-06)

(I based it on the first picture, which has a story. For me, he made use of the rich and the poor.)

Convey Message - Photographs are meant to tell a story and transmit it to the viewers. It is the most convenient way to get across the message without viewers reading many texts or words. Hence, news photographs are a great medium to make the students realize the real scenarios in society. It is first-hand evidence of the true events happening in the country. Additionally, details on these photos hold profound meanings that, if interpreted well, can strengthen the students' understanding and help them draw useful realizations and insights. Photographs are mainly meant to inform everyone and directs them of the important things happening around us. Flower asserted that:

"Kadto nga mga photographs ma'am effective to siya sa pagconvey sa message dali ra masabtan sa audience unsay boot ipasabot ato. Unya instead nga magbasa basa pa ka ug tag-as nga sentence nga in English pa jud samot nga dili masabtan tong picture kay halos kay naa na didto tanan detalye nga nasulod na didto sa picture ma'am ba." (IDI-03)

(Those photographs are effective in conveying the message, it is easy for the audience to understand what it tries to tell. Then, instead of reading long sentences in English that make it harder to understand, those pictures already have all the details.)

Tricky supported the assertions of Flower as she described how convenient photos are in conveying its message to the audience. She affirmed that:

"Kadto nga mga pictures ma'am kay dali rajud nimo mapoint ang buot pasabot niya ma'am.

Makita nimo iyang buot isulti maski way nakabutang other infos didtoa.” (IDI-06)

(It is easy to identify the message of those pictures. You can easily cite the meaning even without additional information stated.)

Besides, Blckmale mentioned that photos served as evidence of the actual happenings in the country. Specifically, he stated that:

“Photos murag serve sya as evidence. Evidence-based ang mga pictures Ma'am ba mura syag 
mag serve as proof to convey a message even though sometimes looks can be deceiving, but the photograph itself can already send a story." (FGD-01)

(Photos may serve as evidence. Those pictures are evidence-based, which serve as proof to convey a message even though sometimes looks can be deceiving, but the photograph itself can already send a story.)

This statement uttered by Blckmale was in congruence with what Aphrodite has to say about photos serving as evidence of true events in society. She said that:

“Para sa akoa Ma'am, bali nag hatag ni sya ug ebidensya Ma'am ba na nahitabo ni tanan. Kay naa man gud uban tao sa storya lang kutob, ug magtuo-tuo sa ingon sa uban masking dili tinood. So, kani sya nga mga pictures kay para ma-inform ta ug para naay magsilbi sya nga evidence." (FGD-03)

(For me, it gives evidence that all of these really happen. Because there are people who are only good at talking and are gullible on what others tell them even if it is not true. So, these pictures will inform us and serve as evidence.)

Lastly, for Sagittarie, photos have the basic purpose of informing the public that many people are suffering. She mentioned that:

"To inform the rest of the citizens in the Philippines are people suffering from poverty and natural disasters, Ma'am. Feel nako kay mag inform lang jud sya Ma'am na ing ani ang nahitabo sa Pilipinas Ma'am.” (FGD-06)

(To inform the rest of the citizens in the Philippines that people are suffering from poverty and natural disasters. I feel that photos inform everybody of the happenings in the Philippines.)

\section{Discussion}

As this study had indicated, its purpose was to establish that online news photographs were dependent on communication and language because they took advantage of specific semiotic properties that were crucial in understanding the social issues in the country. In addition, it aimed to establish the idea that images like online news photographs are interdependent on language using visual literacy. It also aimed to find out the processes through which this shared knowledge will be generated. This qualitative study described the semiotic features of online news photographs by identifying and analyzing the signifier, signified, denotation, connotation, and myth. Next, the phenomenological study aimed to unveil students' perception and understanding of the given photos; and how this creation of meaning helps in forming their own viewpoints concerning current issues in the Philippine context and the development of their visual literacy. The phenomenological study is very much concerned about the human perception of events created from concrete proceedings emphasized through extensive interviews and discussion according to Creswell (2012). Hence, the study focused on what common experiences and insights the participants have encountered and realized in the phenomenon under investigation through in-depth interviews and focus group discussions.

Firstly, this study was gleaned from the Semiotics Theory of Ferdinand de Saussure (1959), which states that persons live in a world shaped by decoded signs found in images, actions, words, and more encountered. The signifier is the material aspect of the sign, while the signified is considered the mental concept. In this study, the signifier refers to the online news photographs, while the signified refers to the mental concept formed upon seeing the signifier. In relation to this, the theory of Order of Signification proposed by Roland Barthes (1977) is used for analysis. This analysis is divided into three concepts: denotative, connotative, and myth. According to Chandler (2017), denotation can be described as the literal, explicit, and obvious meaning of a sign. Next, connotation is used to refer to the understood emotional and socio-cultural meaning of a particular sign. Myths 
signify the naturalized meaning of a sign in a certain culture. It is how a culture indicates and grants meaning to the signs around us. It is a social product in which how culture explains or understands some aspect of reality or natural phenomena.

Lastly, the social semiotics of Halliday (1978) is also an appropriate theoretical paradigm where this study is anchored. Since the study revolved around understanding meaning in a particular society, this theory focuses on creating social meaning (within texts and within society). This theory links social semiotic "signs" as represented in photos to contexts or socio-cultural environments and argues that all "resources" represent an ideology. Specifically, through this theoretical paradigm, I deconstruct the signs (photos) found within the photo under analysis, enabling me to make connections and interpretations to the environments/contexts in which each photo was produced.

In line with these, fifteen (15) online news photographs were selected to deconstruct its semiotic features. Also, fourteen (14) participants from a particular public senior high school in Maco, Davao de Oro, were invited to share their perspectives and insights regarding the online news photographs presented to them. Seven of these participants shared their thoughts in the in-depth interview, while the other seven is in focus group discussion. Both IDI and FGD participants were eager to answer the questions, and they were enthusiastic about sharing their insights with the group. Through their positive disposition, I had rich and comprehensive data sufficient to answer the posted research questions.

Semiotics Features on Online News Photographs. Upon examining each photo to extract its semiotic features, I realized that a single photo could tell a story and deliver a message to the viewers, especially if one exerts effort for analysis. The process of studying the semiotic features of any given photograph can enhance one's comprehension surrounding the context of the photo. It is also important to note that the viewers of these photos play a vital role in constructing meanings and interpreting their experiences and socio-cultural backgrounds. Guided by the presented theory, I focused my examination on the semiotic features of the photographs, namely on their signifier, signified, denotation, connotation, and myth.

First, a signifier refers to any mark, sound, or any perceivable indicator that communicates suitable behavior to a person. Norman (2013) stated that it can be anything used to indicate what affordances things have. In accordance with this, a signifier can be anything quality or property of an object that defines its possible uses or makes clear how it can or should be used. A plain text label can be a signifier. Specifically, the photographs found on online news are signifiers that have a quality that enables viewers to do, think or feel about something.

Just like in the study of Dağ (2010), it gives emphasis on the proper use of signifiers in the illustrations of the characters in books. The signifiers of facial expression and body language are a great tool in understanding the characters' emotions in the books more quickly. If the same notion is applied in the online news photographs, the more comprehensive and detailed a photo will be its intended meaning can be further elaborated. Furthermore, the first semiotic feature utilized in the photo analysis is a signifier, which is a sign. A sign is the combination of a signifier and signified to form a meaningful unit. Bradley (2016) refers to a signifier as a sound, a word, a photograph, or a facial expression. Therefore, the study's primary materials under analysis consisting of fifteen online news photographs are the signifiers where meaning and messages can be further formed and generated. Signifiers can always be around us, and every signifier has a corresponding signified depending on the viewer's culture and background.

The sign may be broken down into two parts, the signifier and signified. According to Hébert (2006), signified refers to the idea or meaning being expressed by the signifier. However, there is no direct relationship between a signifier and a signified, that is, a photo (signifier) may have different meanings depending on the viewer. Meaning is flexible, changeable, and arbitrary. The photographs were then given a corresponding signified in the study based on the mental concept formed from the photos. As stated, signified are the mental representations of a particular signifier. Hence, I looked into the meaning of the photos I perceived to analyze the signified. Signified appears to be dependent on the signifier. You cannot form a mental concept without some 
form of the signifier. Signifier and signified do co-vary, but these are not independent actors in the viewer's perception of a sign. If they are independent, it would be impossible to define an object or concept. In accordance with Slobin (2005), signified forms through the perceived signifier all around us. This is what constitutes a sign. However, it is impossible to have only one absolute meaning for a signifier. This generated meaning is varied from one person to another.

The denotation is the clear description and representation shown by the visual artifact and the most easily understood message in an image. It is the 'literal' content of the image instantly recognized by the viewer. In parallel to this definition of Sanawi (2014), I had described what was happening in the photos, the people, setting and actions, and any other obvious details found in the photos devoid of any subjective evaluations. Indeed, denotative meaning leaves little to no room for interpretations. Rodrigues (2013) has a similar view to the concept of denotation. What the viewer sees and assimilates is the objective, literal and practical copy to a particular referent. In this sense, the photo just says that it is about something, and it only reveals the existence of something without explaining what that thing is. Overall, people's movements, facial expressions, clothing, and gestures were taken into account in their denotative meaning. Also, the situation and setting were clearly described to reveal accurate and comprehensive descriptions of the photos.

In parallel to this, Jewitt and Van Leeuwen (2001) affirmed that in denotation, there is no encoding of a language-like code which must be learned before the message can be deciphered. The denotative meaning is solely constituted by recognizing who or what kind of person is shown in the photo, what he is doing, etc. Looking at a photograph is closely analogous to viewing reality because it provides a definite correspondence to what was in front of the camera. Despite that, this reality is reduced size and enhanced in color. On the other hand, Cuddon (1998) explained that connotation of photos means the implicit and emotional meaning evoked by images over what they actually denote. It is important to note that connotative signs can be personal and individual or general and universal. The meaning of the photos can be mainly associated with the viewer's social, political, and cultural stance and opinions. Overall, it can be implied from the photos that interpretive meaning focuses on the people's values of helpfulness, their fight for survival, Filipino's optimism, the importance of education, people's faith, provision for family, and the significance of following the protocols during this pandemic.

In accordance with this, Bauer and Gaskell (2000) affirmed that in photographic advertising images, the connoted message is a work of interpretation and grasping the image's message, which is underlain and held together by a collection of the denotation of a particular sign. The viewer's task is to interpret by drawing attention to the constructed nature of the photo, for example, by identifying the cultural knowledge that is implicitly referred to by the image. Any signifier may constitute a connotative meaning either positively or negatively. In the study of Zuhdah and Alfain (2020), the result reveals that a word or expression has a denotation and negative and positive connotation. Both negative and positive connotations are possible depending on the viewer or hearer. Thus, a signifier can have countless interpretations. This can be the result of the varied and intricate upbringings that influence the way they comprehend a material.

In addition to this, Bradley (2016) has further explained the concept of connotation. This second level of meaning is an idea or feeling that is invoked by the literal meaning. It is the emotional associations you make with the signifier and not the obvious analysis of what the signifier displays. We do not have the same connotations when we analyze a similar sign. Connotations require context, which is constructed from our unique schemas, culture, and ideologies. Because of this distinctiveness, it means that different people can interpret the same sign in different ways. Moreover, myth is the interpretive meaning of the photograph, which was linked to the norms and culture of the country. To Gaines (2001), the myth analysis is intended to show how communication happens wherein meaning formed always sustain the potential arbitrary nature of communication. Particularly, myth analysis attempt to shift our focus on the apparent meanings of a particular signifier to the context that constructs its meaning. However, the ideological implications of cultural mythologies are particularly problematic in the sophisticated contexts of mass media. Only when media literacy informs society

42 Consortia Academia Publishing (A partner of Network of Professional Researchers and Educators) 
to read media critically will the form of those communications be altered to meet the evolving consciousness.

Also, Ming and Yan (2014) recognize myth or mythology as a strategy of language which contains two mechanisms, its naturalizing functions, and generalization. When metaphor and connotation connect irrelevant things, naturalizing happens, while generalization works when metonymy and metalanguage highlight associations and produce imagination and similarity. Simply put, myth occurs when a viewer connects ideas that emerged from a photo and applies it in a larger scope. When connotation and metalanguage, metaphor, metonymy, generalization, and naturalizing work together, mythology appears.

In relation to this idea, signs echo an ideology of a country being reflected on the myth formed. For instance, the study of Kükürt (2016) in which textbooks used in the schools are full of symbols of capitalism, or the signs in which capitalist social structure is mythicized. Hence, one can conclude that the signs representing the transition to modernism in their country present the basic building blocks of capitalist power such as development, industrialization, and progress as myths by means of the signs included in the images and the story formed by the mythical presentation thereof.

In line with this concept of myth, my study shows interpretations of the online news photographs in relation to the Philippine context. It revealed the country's overall situations and sentiments, which are vital in understanding the Filipinos' current issues, concerns, hopes, and sensibilities. It was exhibited in the analysis that formed the myth centers on Filipinos' values and faith, means of survival amidst pandemic and natural calamities, their optimism, the importance of education, and obeying protocols.

Moreover, Bignell (2002) affirmed that myth refers to ways of thinking about people, places, products, or ideas constructed to deliver a certain message to the reader or the viewer. For instance, an advertisement for shoes which contains a photograph of someone stepping out of a Rolls-Royce car is not only denoting the shoes and a car but attributing the connotations of luxury which are available through the sign 'Rolls-Royce' to the shoes, suggesting a mythic meaning in which the shoes are part of a privileged way of life. The bringing-together of signs and their connotations to shape a particular message makes a myth. Myth is not a clear language, but one that picks up existing signs and their connotations and orders them purposefully to play a particular social role. Students' understanding of online news photographs affects their personal viewpoints regarding issues in society. In identifying the students' understanding regarding the given photographs, the validated guide questions were utilized to gain relevant answers from interviews and discussion. These data from the participants were transcribed and analyzed to develop essential themes to answer the second research question. Overall, six essential themes emerged that shed light on the inquiry regarding their viewpoints about issues in society as reflected on their understanding of the online news photographs.

First, personal concern was revealed in Alpay, et al. (2019) findings, stating that Gen Z is identified as a generation that cares deeply about social issues. This concern occurs through being aware of social issues and problematic situations in the country and expressing their views and positions on this matter in various ways. To convey these concerns, they act by writing their thoughts through a post on social media or personally sharing ideas with friends, parents, and colleagues. Also, students are inspired to make a change in the world by contributing their knowledge, awareness, and supplies to help the community and by studying well and educating themselves to better help in the future.

In addition, in the study of Nicomedes, et al. (2020), the social challenges, especially during pandemic amplifies the existing definitions of life, death, and existence. The respondents have acquired coping mechanisms skills to achieve their personal goals and social interests. Hence, their view on society changed due to some external factors that changed their outlook on life. Coping is an important thing that needs to master. It involves contemplating the current situations, such as their future, the relief goods they are receiving, and the news they are acquiring.

The mentioned positive disposition of students in the previous paragraphs does not hold true in the study of 
Pastor (2020) regarding Filipinos' sentiments on social issues. The study has recognized that the general sentiments of Filipinos regarding issues in society lean towards more on the negative side. The sentiment shows that one basic need is affected regarding the food supply and support from the government. Personal concerns, mainly to think and act on something for the betterment of society, may not be apparent in the said study. However, it was suggested that intervention should be done based on the requirement of the Filipinos who encounter problems in the food shortage. Everyone should support to flatten the curve for the operations and life back to normal.

On a more optimistic tone, the study of Lucman (2020) has proved that there are still social justice skills among the students. Social justice means the view that everyone deserves equal political, economic, and social rights. Personal concerns are still there when they have exhibited an ability to take responsibility and initiative for their own learning experience, hone their communication skills, and develop empathy towards other people. Also, it was revealed in the study of Tancinco and Concepcion (2016), knowing the social issues and problems is prevalent among students. Because of this, another way of showing concern is through students always maintaining their self-discipline in terms of academic matters. Seeing the country's present conditions, they are eager to take responsibility and accountability in studying their lessons well to achieve satisfactory academic performance.

The level of public awareness of students generally intensifies as the year level increases. Thus, senior high school students have a wider information channel on various social issues than any grade level. Barreda (2018) states the factors that could influence this awareness level: mass media, training, seminar, internet, and social media. Because of this, senior high school students have more understanding of public concerns and social problems, which builds a sense of urgency to spread awareness to other people, to help them understand the situation and what must be done to improve each and everyone's life amidst crises. In education, the COVID-19 pandemic has brought unforeseen challenges to the teaching-learning process. In the study of Tria (2020), it reiterates the government's provision and maintenance of quality education despite the quarantines and lockdown. The government finds possible means to deliver learning straight at home, which is the new normal educational policy. Public awareness is sustained to ensure that accurate information is provided to the people.

Mentioning the spread of awareness, Baloran (2020) stated that the students were aware of the COVID-19 pandemic and acquired adequate knowledge about this worldwide concern. Students understood how the virus is spread, its symptoms, and the precautionary measures needed to be done by both individuals and the general community. Due to this understanding, students formed varied suggestions to alleviate the problem in the country. Hence, they also stated the importance of following the protocols and mass testing. Additionally, risk and crisis communication are a vital part of the local government unit's response and management. The clear and prompt spread of information becomes a defining factor for mutual trust-building among people living in a community. Similarly, Flores and Asuncion (2020) recognize the ability of the LGUs to become enablers of mutual trust and collective action in health emergencies is a crucial fragment of a more trusted government.

Correspondingly, Mendoza, et al. (2017) disclose that Filipinos are forthright in expressing their public concerns that need to be addressed. As being aware of the current problems, they became keener in proposing policies and giving emphasis in fixing the current programs of the government. They call for simple and efficient government transactions and services. Also, students displayed a satisfactory level of knowledge and practiced necessary preventive measures pertaining to the current pandemic. They are aware of the happenings and the consequences of not following the set protocols. Thus, it can be discerned that the awareness of students has influenced their attitude towards social issues. Dalanon, et al. (2021) affirms that students display a certain level of optimism that the Philippines will win the war against the pandemic and their families will survive this ordeal.

The clarity of the message regarding the latest happenings in the country opens the students' minds that enabled them to form their own coping strategies. Some of these strategies involved their dependency on parents, resiliency to natural calamities, having faith, and practicing the culture of bayanihan. Songcayaon, et al. (2020) 
asserts that having a clear perspective of the social concern through images or their own experiences has significantly influenced their resilient attitude towards life. Amid the global crisis, youth have seen the importance of education. This was revealed on the study of Rotas and Cahapay (2021) when they asserted that remote learning is the alternative way to deliver education at home. But this delivery mode poses stress, especially in the Philippines, where resources are a real problem. Filipino youth have realized these challenges and have employed coping strategies to alleviate these hardships. Resiliency is evident to Filipinos, and whatever problems they may encounter, they can gradually adapt and rise from all adversities.

In parallel to this, Miranda and Cruz (2020) highlighted Filipino students' optimism and well-being, which, in general, reflects their resilient attitude. Being hopeful that every challenge will be overcome and adaptability to whatever problems they may encounter has been seen as an intervention to support the psychosocial development of students. Seeing the issues through online posts and experiencing them directly widens the view of the students, and it helped them form a positive attitude in overcoming any social problems. It was also emphasized in the study of Sulistyo and Noh (2020) that media images play an essential role in the formation of values, especially in the younger generation. Pictures displayed in strategic places can convey a clear message to the viewers especially used as a solution to overcome the turmoil in the community. Further, students need to pay attention to utterances in the print media/ images in the hopes of receiving the intended meanings and be able to apply those in their daily lives.

In support of this idea, according to Tovankasame and Labayo (2021) Filipinos respond flexibly towards environmental transition and policies during calamities, especially during pandemic. They find ways to continue their works at home and to continue their religious practices via online. It may suggest an unusual manner of the past activities but learning to adapt helps lessen the stress. Overall, Filipinos can find new meanings for their actions to accept the current changes. Likewise, Arnado and Bayod (2020) affirmed this by stating that Filipinos rely on their personal strengths to survive the challenges caused by pandemic, although at times, they feel hopeless and restless. Photographs relating to the pandemic and other social issues have proliferated throughout the internet. Understanding the present scenario, Filipinos find their strength by having a positive mindset, engaging in activities, sustaining healthy relationships with people, and having faith in God.

Being a steward of the importance of news, they have seen social media as a medium to acquire accurate news and inform the government of their needs and demands. As stated by Shen, et al. (2021), with all the disasters and challenges faced by Filipinos, social media is an important channel for people to request supplies and goods from the government and obtain information on disaster areas. In parallel to this, the study of Stewart (2019) had also revealed that students opt to get updated with news from social media. They interacted with news and updates via social networks because of its convenience. Most recent happenings from every part of the country are readily available online. Students can interact through this easier access to the latest updates by liking or commenting whether they agree or disagree with the presented information. In addition, young people have a greater interest in seeking out the events in the social and political arena in the country. Keeping up to date with the latest happenings is very important for young citizens. It was revealed by Catalina-García, et al. (2019) that youths have considered checking their online networks and social media as a vital regular activity. This further suggests that youngsters have confidence in online networks' effectiveness and consider that their participation and involvement with the latest news through social media should also be known and expressed.

Indeed, social media platforms like Twitter, Facebook, Instagram, and YouTube are among the primary means for Filipinos to keep track of the progress made by the government and other persons-in-authority. To ensure that proper information dissemination was made, and instant reports are sent, people monitor these online. Catalina-García, et al. (2019) contends that the role of social media has become more prominent than ever before, especially because of its convenience and accessibility. Because of the great impact of social media on Filipino's news consumption, the public eye has become more vigilant than ever. Balod and Hameleers (2019) have seen the critical importance of media in transmitting information to the public. Media is in a unique position to act and react and report not only the truth but also the mistruths. Thus, journalists must be ready to adapt to the 
ever-changing times and commit to constant vigilance in serving the public. Seeing the recent happenings through online and social media shapes the sociological imagination of the students. Walsh (2020) has found out that students form meaning during the pandemic, and they can learn from the past and reimagine their future. Because of the distress and loss, they have endured, students have developed resilience and hope in these difficult times. The perspective of students towards social issues has gradually widened because of the news they consumed daily.

Likewise, students have displayed a satisfactory level of emotions towards school and education amidst the closure of educational institutions. Faced with adversities brought about by the pandemic, students are still hopeful and optimistic that they can continue and learn at home. Consequently, Mirahmadizadeh, et al. (2020) further indicate that despite the enforced status quo, they showed enthusiasm towards learning and schools. However, it was revealed in the study of Tee, et al. (2020) that there is a portion of the population that has a different perspective on the matter. Because of various social concerns, one-fourth of the respondents have moderate to severe anxiety, and one-sixth reported having moderate-to-severe depression. It is inevitable that people will have a negative mindset with the overwhelming issues Filipinos faced as a country. In a general view, the standpoint of the respondents about this matter has drastically changed, seeing the suffering and torment of fellow citizens they see on the television and other various online news platforms.

In addition, in the educational arena, most participants share their concerns about their career prospects for the future. They have surmised that online classes will not suffice the competencies that they must acquire. There is also a worry about getting the necessary skills needed for their future profession if their learning is jeopardized today because of the pandemic. Undeniably, realizing the overwhelming concerns about education like restrictions and lockdowns, especially through online news, Cleofas (2020) questioned the general condition of education, which further affects their personal state as a student in the country. In general, Filipinos have their ways to cope with difficulties as influenced by three domains, namely family, religion, and community. These coping mechanisms in dealing with adversities are manifested positively or negatively and are directed towards resilience. Further, Nicomedes, et al. (2020) states that there is a cyclic pattern where a person learns to adapt and continues to influence the person's perception of the problem. Overall, because of what a person feels and experiences in the family, his/her faith and community play a role in seeing the entirety of the problem. Filipinos may have opposing coping styles, but it led towards resilience.

In accordance with this study, De Leon (2020) also discloses that Filipino high school students acquire a sense of national pride mainly through access to information influenced by personal, socio-political, and socio-economic issues. Even with all the unfavorable circumstances slackening the country's progress in almost all aspects, students can still show their pride by depicting an engaging and positive social experiences and cultural dimensions. They are generally hopeful and optimistic that the country will rise from any adversities, reflected in their civic involvement. The Filipino youth supports community development and civic action. Arguelles (2020) reinterpreted the youth's political participation to reveal how they adapt to the ever-changing Philippine and global societies and the issues their generation faces and embraces in their everyday lives. As opposed to the accusations that millennials are politically apathetic, youth have been considerably involved in the country's defining social and political issues in a way fitting to the current generation.

In the Philippines, Sangguniang Kabataan, a council meant to represent youth in the barangay, offers opportunities for them to participate in civic activities. Bautista (2020) asserts that in realizing the difficult situations in their family and personal experiences, youth acquire attitude and willingness to extend help in their own various ways. Media use has also significantly affected their attitude in service to their community. Likewise, in the inquiry of Palomares, et al. (2021), the local government in our country provides a space for youth to have a participation in governance in the barangay. Youth are both intrinsically and extrinsically motivated to participate in politics. The high level of political participation is reflected in their involvement in different kinds of barangay programs and policymaking. Social media, peers, and online platforms have influenced how youth think at present. They became more intrinsically and extrinsically motivated to act for the

46 Consortia Academia Publishing (A partner of Network of Professional Researchers and Educators) 
benefit of the community their living. The claim that students are politically impassive and indifferent generation is denied by Cabo (2018). She stated that youths are interested in politics and have critical views regarding social and political issues. In a technology-driven generation, they are more aware of what is happening around them. They engaged themselves in civic activities to show their aspirations and hopes for the future of the country. Today's youths are a promising generation full of energy and enthusiasm to help and support their community.

Ways on how semiotic features of online news photographs aid the visual literacy of students. In identifying ways on how semiotic features of the given photographs can aid in students' visual literacy, the validated guide questions were utilized to gain relevant answers from interviews and discussion. These data from the participants were transcribed and analyzed to develop essential themes to answer the third research question. Overall, three essential themes emerged, which shed light on the inquiry regarding how semiotic features of online news photographs aid students' visual literacy. Photographs offer visual metalanguage wherein meaning is generated, adding to the intended message that news is trying to convey. With the prominence of an image in this technology-driven world, national identity and national consciousness are propagated. Guedj (2019) states that the visual elements are prominent in creating a national consciousness to explore the contribution of the press in instilling the visions for national identity. Students can be informed of the real happenings in the society and instill in their mind a general understanding of the failures, progress, hopes, and desires of the nation.

Allan and Peters (2020) recognized the varying degree of visual metalanguage purveyed in political cartoons, GIFs, memes, images, and video remixes in the media. These materials create a phenomenon by situating the problem within the context of a person's daily life and, in this way, utilize universal values as a means for the readers to identify the image and their intended message. Photographs and other visual materials enable a person to understand and create a meaningful message out of the situation presented. Moreover, pictures and images related to social issues provide a suitable environment wherein students can apply logical arguments in an authentic scenario. These materials enable the students to be engaged with relevant issues in society today. This is supported by the study of Navera, et al. (2019) when they contended that the details present in the photo can provide meaningful insights and use them for a productive engagement. Photographs can be a great tool for understanding the issue and where students stand on these.

Knowledge of oneself and norms and visual competency are active while viewers interact with social media images. There are various levels of interpretations in visual materials, and students will interact with the messages. By saying this, students are utilizing higher order thinking to understand pictures and images presented. According to Stahl and Kaihovirta (2019), a metalanguage in visual materials enables students to deepen their knowledge of social issues in the country. To strengthen communication, images are used to express emotions, capture attention, and convey a large amount of information in a short amount of time. Flynn (2019) affirms that many people in different fields of expertise provide photographs to enrich public relations and communication management Technological innovations pave the way for fresh possibilities in the way we interpret images.

Also, Goens (2021) agreed that photographs convey seemingly complicated ideas clearer and simpler than written words. Visual arts and photographs are vital for conveying an instantaneous response of joy, humor, pain, or historical significance. They highlight passion and point of view depending on the viewer's interpretation of the photographer's intentions. Specifically, photos could evoke a certain emotion. For instance, it was stated in the study of Angell (2020) that during community quarantine, a photograph in news stories that shows an empty shelf caused the viewers a feeling of panic and anxiety. It instigates people to follow the buying hysteria, or else they will be left with no food on their tables during a lockdown. Truly, photographs convey negative or positive emotions and send a pro-social message.

Another example where photos are powerful in evoking certain emotions in the viewers is the photographs of the war on drugs of Duterte's administration. In the study of Treceñe, et al. (2019), respondents expressed negative emotions, specifically sadness, pain, and pity. They have stated that abuse of drugs will be avoided if 
the child were appropriately nurtured. Photographs can reflect the state of the different aspects in a country as it affects the smaller scales of society. In news photography, where social issues and dynamics are explored, investing in the art of conveying the emotions on images taken by photographers is a must. Chen (2020) argues that the detail mining in capturing a scene must be considered to convey the intended message to the audience. The details of the photo are a critical aspect of news photography so that the viewers can understand social concerns.

Aside from expressing emotions, photographs can also convey messages for humanity and serve as transmitters of social criticism. Briandana and Mukti (2019) stated that this medium sends forth meaning to the viewers about political, environmental, and social matters. The denotative and connotative meanings of a photograph were essential in coming up with the message that it would like the viewers to comprehend. Furthermore, Nuzzaci (2019) emphasized that effective communication is not only on one's ability to use verbal language but also on the ability to convey messages through visual arts and photographs. The utilization of visual thinking by using media and technology is highlighted for it also measures our understanding of the social issues around us virtually. Visual information supports the understanding of textual information, and that people can learn better from photos than words.

Language barriers are inevitable, which prevent people from understanding one another. This problem is a challenge for effective communication between a sender and receiver. However, this lack of communication or miscommunication can be prevented by using visual methods of communication to explain a complex concept. In accordance with the study at hand, Flynn (2019) asserts that photographs and other visual mediums are important to send an idea or message to an audience clearer, simpler, and quicker. In social media, Tamble (2019) confirmed that photos, videos, and infographics are more effective in the success of content marketing and social campaigns than the text updates, as evidenced by the more likes, shares, and engagement of the former than the latter. These visual materials grab the attention of the viewers faster and more efficiently than words. Thus, photographs are a very good storyteller that can add value to a content and convey messages more effectively than just plain text.

\subsection{Implications for Language Teaching}

Photographs, incorporated in the teaching-learning process, may lead to developing and improving students' visual literacy. As stipulated in the vision of the Department of Education, which states that students are called to contribute meaningfully to building the nation, it is of great importance for them to be informed of the happenings in the society which will help shape their minds and sensibility of being future builders of the nation. Hence, the results of the analyses in the semiotic features of the online news photographs (signified, signifier, denotation, connotation, and myth), as well as the themes that emerged in the interview and discussions, may be used as a basis for teaching students as they embark on their journey as critical thinkers of the 21 st century.

Firstly, it is implied based on the result that through image-analysis activity in the classroom, students may develop their communication and comprehension skills as they share their understanding of what certain photos intends to express. Through this, they may develop an awareness of social events, improve their critical thinking ability, amplify their observation and visual literacy in English subject. This is parallel with the findings of Layalle and Briesmaster (2017) study, which advocated the importance of integrating picture descriptions in classroom activities to enhance student's overall participation and communication skills.

Additionally, pictures may enhance the power of imagination of the learners. The use of photos for educational learning and intention is vital. In language teaching, the utilization of these materials can be optimized to heighten students' creativity. Hence, curriculum planners may take into consideration the importance of reinforcing the usage of photos in textbooks and other learning materials (Rabbani et al., 2015). The result suggests the significant contribution that critical analysis of photos may bring in an English classroom. By designing appropriate teaching strategies using photos and images, students may draw insightful ideas and 
learn from their society. Additionally, they may later use the classifications and analyses made on each semiotic feature as a reference when conducting their own study.

Furthermore, this study may assist teachers in other ways to instruct their students on the use of semiotics through photo-elicitation using the language. By making the students identify the signifier, signified, denotative, connotative, and myth of the photos, they may improve their visual literacy to effectively interpret and draw conclusions from images and pictures. Therefore, students may be exposed to social issues as teachers utilize relevant social content in their classes and give students the avenue to express their ideas and concerns regarding happenings in the country. Helping students comprehend the concept of semiotics may allow them better to understand the various signs and symbols around them. Through this understanding, students can grasp the meaning these signs try to express and help them better understand their society. Thus, this study paves the way for future researchers to explore the semiotic fields and analyze photos and moving pictures and videos.

The photo-elicitation technique prompts new reflections on the students' perspectives on cultural identity then and now and lessons for today's youth (Giancarlo et al., 2021). As a teaching tool, photo-elicitation enables students to visualize their everyday lives and experiences, elicits meaning and emotion, enhances critical consciousness, and promotes visual literacy. This was supported by the study of Tillman (2012), who stated the importance of visual literacy among learners. In today's world, we are more exposed to more visuals than before. Thus, aside from the concepts of reading and writing, visual literacy must be included in the teaching-learning process. Findings from the study suggested that developing this type of literacy will assist students in learning better how to decipher, understand and communicate with photos. It is a great success in the education system if students are taught what is in a book and how they apply it to society.

Furthermore, visual literacy is a set of vital competencies for 21 st-century learners. Surrounded by visual media does not mean that students can find suitable images and recognize their message and cultural context (Matusiak et al., 2019). Therefore, studying semiotics and its pertinent signs and symbols is not that easy, especially when discussing students' visual literacy. Picture analysis may aid students' visual literacy.

Lastly, the result implies that visual literacy is an essential skill that students need to enhance and develop. From the findings, it may be suggested that students can interpret and give various and elaborated insights if they are just given the suitable activity and tasks to showcase this skill. In the teaching-learning process, teachers need to realize the importance of incorporating photographs in classroom activities. Aside from exercising the target language by sharing their insights and interpretations of the photos, they can also be aware and well-equipped of the important events in the country.

\subsection{Implications for Future Research}

Semiotics is often associated with analysis on the linguistic level. Still, this study gives another perspective as it tries to probe the analyses of other sign and symbol systems besides language alone. The messages and meanings beneath these signs enable further understanding of the concept or context of these signs. Allen (2017) expressed how significant semiotics is in the field of communication research. This kind of inquiry examines the association between signs and their roles in how people create meanings daily. Ibrahim and Sulaiman (2020) emphasized how important semiotics in the field of communication is. In this modern era, we are trapped in the complexity of meanings of the sets of signs and symbols all around us. Exploring semiotics in different fields like media, film, and music is vital in understanding the true meaning of symbols or signs used in a communication process. Hence, this study urges future researchers to traverse different communication platforms and fields where signs and symbols are prevalent and necessary in delivering meaning to target viewers. Moreover, semiotics is also used in many fields of study, including anthropology, medicine, psychology, art, cultural studies, media analysis, religion, and philosophy (Dunleavy, 2020). Therefore, it can be suggested to apply semiotics in other fields of interest. Thus, future researchers can interpret artworks, advertising, films, and other situations that they may interpret using semiotic analysis. 
Moldez, C., \& Gomez, D.

In addition, it may be suggested that a greater number of participants may be invited from different tracks and strands for the interview and discussions for future research. This is to solicit an ample amount of data and varied analysis. Semiotics is the science that mostly explores the signs and the influence they have over interchanging ideas. It mainly deals with signs and uses those signs to aid interactions. Thus, utilizing the ideas of varied participants from various backgrounds and inclinations can make future inquiries interesting and comprehensive. To conclude, this study gives future researchers an avenue to expand the exploration of semiotics across different fields and platforms. Signs and symbols are around us, and this type of analysis may shed light on the ambiguity of meanings brought about by the audience's background knowledge, upbringing, and culture.

\section{References}

Abuarqoub, I.A. (2019). Language barriers to effective communication. https://www.redalyc.org/jatsRepo/279/27962177008/html/index.html

Adams, T. E. (2008). A review of narrative ethics. https://doi.org/10.1177/1077800407304417

Akaranga, I. \& Makau, B. K. (2016). Ethical considerations and their applications to research: A case of the University of Nairobi. https://profiles.uonbi.ac.ke/kuria_paul/files/429-825-2-pb.pdf

Aljoundi, E. K. (2013). Semiotic analyses of an advertising campaign. https://doi.org/10.13140/RG.2.1.1119.0168

Allan, S. (2015). Photojournalism and citizen journalism. Taylor and Francis Online. https://doi.org/10.1080/17512786.2015.1030131

Allan, S., \& Peters, C. (2020). The Visual citizen in a digital news landscape. Communication Theory. https://doi.org/10.1093/ct/qtz028

Allen, M. (2017). Semiotics. Sage Publications. https://doi.org/10.4135/9781483381411.n560

Alpay, P. M. S., Aquino, K., Barcelona, 1., Basquez, N., Bustamante, J. R., Borja, J.F., Carabeo, D., Casiano, M.P., Palad, F., Ruiz, A.S. \& Soriano, P.R. (2019). From Pa-Woke to Woke: Profiling the Filipino Gen Z. file:///C:/Users/User/Downloads/From_Pa_woke_to_Woke_Profiling_the_Filip.pdf

Aluwihare-Samaranayake, D. S. (2012). Ethics in qualitative research: a view of the participants' and researchers' world from a critical standpoint. https://doi.org10.1177/160940691201100208

An Act Prescribing the Intellectual Property Code and Establishing the Intellectual Property Office, Providing for Its Powers and Functions, and for Other Purposes act of 1997, Republic Act No. 8293, § 184. https://www.officialgazette.gov.ph/1997/06/06/republic-act-no-8293/

An Act Protecting Individual Personal Information in Information and Communications Systems in the Government and the Private Sector, Creating for this Purpose a National Privacy Commission, and for Other Purposes Act of 2012, Republic Act No. 8293, § 4. https://www.officialgazette.gov.ph/2012/08/15/republic-act-no-10173/

Angell, R. (2020). Study shows photos of empty supermarket shelves instigate panic buying. https://www.southampton.ac.uk/news/2020/03/angell-panic-buying-study.page

Arackal, F. (2015). Semiotics and media content. In S. S. Sebastian (Ed.), The symbolic world: Construction and deconstruction (Annual Series, Vol. 16). https://www.academia.edu/36357060/Semiotics_and_Media_Content

Arguelles, C. V. (2020). “Apathetic Millennials? The Personal Politics of Today's Young People. University of Santo Tomas Publishing House. file:///C:/Users/User/Downloads/Apathetic_millennials_The_personal_polit.pdf

Arifin, B. M. A. (2018). Ethical considerations in qualitative study. International Journal of Care Scholars. https://journals.iium.edu.my/ijcs/index.php/ijcs/article/view/82/27

Arifin, T. S. N. (2019). Representation of Public Space in the Photo (Photojournalism Semiotic Analysis by Peter Bialobrzeski). https://journal.uii.ac.id/CCCMS/article/download/12675/9154

Arnado, J., \& Bayod, R. (2020). Help seeking behavior of young Filipinos amidst pandemic: The case of Cor Jesu college students. Eubios journal of Asian and international bioethics.

50 Consortia Academia Publishing (A partner of Network of Professional Researchers and Educators) 
Looking at the bigger picture: A semiotic analysis on online news photographs

Atkinson, P., \& Delamont, S. (2006). In the roiling smoke: Qualitative inquiry and contested fields. https://doi.org/10.1080/09518390600975974

Balod, S., \& Hameleers, M. (2019). Fighting for truth? The role perceptions of Filipino journalists in an era of mis- and disinformation. Sage Journals. https://doi.org/10.1177/1464884919865109

Baloran, E. T. (2020). Knowledge, attitudes, anxiety, and coping strategies of students during Covid-19 pandemic. Journal on Mental Health. https://doi.org/10.1080/15325024.2020.1769300

Barreda, A. B. (2018). Assessing the level of awareness on climate change and sustainable development among students of Partido State University, Camarines Sur, Philippines. Journal of Sustainability Education. http://www.susted.com/wordpress/wp-content/uploads/2018/02/Barreda-JSE-Feb-2018-Arts-Issue-PDF. pdf

Barroso, P. M. (2020). Visual literacy and visual rhetoric: images of ideology between the seen and the unseen in advertising. IGI Global. https://www.igi-global.com/chapter/visual-literacy-and-visual-rhetoric/236551

Barthes, R. (1977) Roland Barthes, trans. R Howard. Berkeley: University of California Press. https://monoskop.org/images/b/b3/Roland_Barthes_by_Roland_Barthes.pdf

Bassey, M. (1981) Pedagogic Research: On the relative merits of search for generalisation and study of single events. https://doi.org/10.1080/0305498810070108

Batu, B. (2012). An overview of the field of semiotics. https://www.researchgate.net/publication/257716722_An_Overview_of the_Field_of_Semiotics

Bauer, M. W., \& Gaskell, G. (Eds.). (2000). Qualitative researching with text, image and sound: A practical handbook for social research. Sage Publication. http://eprints.lse.ac.uk/8031/

Bautista, A.R. (2020). Exploring political socialization and political participation: The Filipino youth and the sangguniang kabataan in Caloocan city’s first legislative district. Taylor and Francis Online. https://doi.org/10.1080/0145935X.2020.1859364

Berger, J. (1978). Görme Biçimleri. İstanbul: Metis Yayınları. https://www.pdfdrive.com/g\%C3\%B6rme-bi\%C3\%A7imleri-john-berger-d117481442.html

Bignell, J. (2002) Media Semiotics: An Introduction, 2nd edn, Chapter 1, Manchester/New York, Manchester University Press.

Bitsch, V. (2005) Qualitative Research: A Grounded Theory Example and Evaluation Criteria. Journal of Agribusiness, 23, 75-91.

Bradford, W. C. (2011). Reaching the Visual Learner: Teaching Property Through Art. https://ssrn.com/abstract=587201

Bradley, S. (2016). Denotation and connotation - Literal and implied meaning. https://vanseodesign.com/web-design/denotation-connotation/

Braun, V., \& Clarke, V. (2006). Using thematic analysis in psychology. Qualitative Research in Psychology, 3(2), 77-101.

Braun, V., \& Clarke, V. (2013). Successful qualitative research: A practical guide for beginners. London: Sage.

Briandana, R., \& Mukti, D.A. (2019). Understanding photography representation: Humanism and social criticism in social media. https://doi.org/10.2991/icpc-18.2019.13

Brownlow, C., \& O’Dell, L. (2002). Ethical issues for qualitative research in online communities. https://doi.org/10.1080/0968759022000010452

Brumberger, E. (2011). Visual literacy and the digital native. An examination. Institute of Education Sciences. https://eric.ed.gov/?id=EJ931652

Burns, N., \& Grove, S.K. (2003). The practice of nursing research: Conduct, critique and utilization. Toronto: WB Saunders.

Butler, T. (2015). Fashion photography as semiotics: Barthes and the limitations of classification. https://news.mongabay.com/2005/04/fashion-photography-as-semiotics-barthes-and-the-limitations-of-c lassification/

Cabo, W. L. (2018). Youth and political participation in the Philippines: Voices and themes from a democracy project. https://so03.tci-thaijo.org/index.php/jopag/article/view/123298

Caple, H. (2016). Photojournalism: A social semiotic approach. https://doi.org/10.1177/1470357215608995 
Moldez, C., \& Gomez, D.

Carullo, C. C., Fajardo, A. E., Gestre, A. F. \& Rañeses, M. G. (2019). Albayanos' perception on the online media's graphic presentation of tragedies.

https://www.academia.edu/38678050/Albayanos_Perception_on_the_Online_Medias_Graphic_Presenta tion_of_Tragedies

Caruncho, E.S. (2020). Contemporary photography in the Philippines crosses more boundaries. https://lifestyle.inquirer.net/359394/contemporary-photography-in-the-philippines-crosses-more-bounda $\underline{\text { ries } / 15 / 30}$

Catalina-García, B.; García-Jiménez, A. \& Menor Sendra, J. (2019). "Social and political engagement of university students in the digital sphere: Uses of social networks for citizen participation". https://www.academia.edu/39897471/Social_and_political_engagement_of_university_students_in_the _digital_sphere_Social_network_uses_for_citizen_participation

Chai, C. (2019). Enhancing visual literacy of students through photo elicitation. https://doi.org/10.1080/1051144X.2019.1567071

Chandler, D. (2017). Semiotics for beginners: Denotation, connotation and myth. http://visual-memory.co.uk/daniel/Documents/S4B/sem06.html

Chattopadhyay, B. (2017). Deconstructing messages using semiotic analysis. https://lifeasahuman.com/2017/business/marketing/deconstructing-messages-using-semiotic-analysis/

Chen, Z. (2020). Analysis of emotional integration in photojournalism. http://clausiuspress.com/conferences/LNEMSS/FMESS\%202020/20FMESS066.pdf

Cheng-Tek Tai, M. (2012). Deception and informed consent in social, behavioral, and educational research (SBER). https://doi.org/10.1016/j.tcmj.2012.05.003

Clayton, I.S. (2019). 'Meme-orising' visual literacy in the classroom: Investigating the role of meme in literacy development. https://hdl.handle.net/10539/27999

Cleofas, J. V. (2020). Life Interruptions, Learnings and Hopes among Filipino College Students during COVID-19 Pandemic, Journal of Loss and Trauma. https://doi.org/10.1080/15325024.2020.1846443

Cohen, D., \& Crabtree, B. (2008). Semi-structured interviews. Robert Wood Johnson Foundation Qualitative Research Guidelines Project.

http://www.sswm.info/sites/default/files/reference_attachments/COHEN\%202006\%20Semistructured\% 20Interview.pdf

Collins (2020). Definition of connotations. https://www.collinsdictionary.com/dictionary/english/connotation

Cormack, A. (2016). A data protection framework for learning analytics. https://doi.org/10.18608/jla.2016.31.6

Creswell, J. (2012). The analysis of qualitative data. http://gato-docs.its.txtstate.edu>Creswell-TheAnalysisofQualitativeData.pdf

Creswell, J. W. (1998). Qualitative inquiry and research design: Choosing among five traditions. Thousand Oaks, CA: Sage Publications.

Cuddon, J. A. (1998). The Penguin Dictionary of Literary Terms and Literary Theory. London: Penguin books.

Dağ, E. S. (2010). Examination of facial expressions in illustrated pre-school children books in relation to "Signifier and Signified". Procedia-Social and Behavioral Sciences, 2(2), 2957-2961.

Dalanon, J., Redoble, R., Belotindos, J. A., Reyes, C. D., Fabillar, J., Armero, M. S., \& Matsuka, Y. (2021). Adequate knowledge of COVID-19 impacts good practices amongst health profession students in the Philippines. https://doi.org/10.1101/2021.02.18.431919v1

Debes, J. L., \& Williams, C. M. (1978). Visual literacy, languaging, and learning. Provocative Paper Series. Washington: Visual Literacy Center.

De Leon, R.C. (2020). A qualitative description of Filipino junior high school students' national pride.

de Saussure, F. (1959) [First published 1916]. Course in general linguistics (PDF).

https://warwick.ac.uk/fac/arts/english/currentstudents/undergraduate/modules/fulllist/first/en122/lecture list2019-20/saussure_course_in_general_linguistics.pdf

Denzin, N. K., \& Lincoln, Y. S. (2008). Introduction: The discipline and practice of qualitative research.

Denzin, N. K. (2010). The Qualitative Manifesto: A Call to Arms.

Dunleavy, D. (2020). Visual Semiotics Theory Introduction to the Science of Signs. Routledge.

52 Consortia Academia Publishing (A partner of Network of Professional Researchers and Educators) 
Looking at the bigger picture: A semiotic analysis on online news photographs https://www.taylorfrancis.com/chapters/edit/10.4324/9780429491115-14/visual-semiotics-theory-dennis -dunleavy

Džanić, M. (2013). The semiotics of contemporary advertising messages: Decoding visuals. https://hrcak.srce.hr/file/165534

Fedorov, A. (2015). Semiotic and identification analysis of media texts on media education classes with students. https://papers.ssrn.com/sol3/cf_dev/AbsByAuth.cfm?per_id=1950771

Fenton, B. \& Mazulewics, J. (2008). Trustworthiness. Natural Leadership Instinct. http://www.omnivise.com/research/trustworthiness.htm

Fidouh, D. (2014). Communicative semiotics in everyday life (Cultural criticism - the image in the 21st century). http://ethos.bl.uk/OrderDetails.do?uin=uk.bl.ethos.699242

Flores, R., \& Asuncion, X.V. (2020). Toward an improved risk/crisis communication in this time of COVID-19 pandemic: A baseline study for Philippine local government units. https://doi.org/10.22323/2.19070209

Flynn, T. (2019). A picture is worth a thousand words: Using behavioural insights in visual communication. https://instituteforprorg/a-picture-is-worth-a-thousand-words-using-behavioural-insights-in-visual-com munication/

Free Dictionary. (2020). News photography. https://www.thefreedictionary.com/news+photography

Furigay, J. L. (2016). Viewing must be taught. https://www.pressreader.com/philippines/philippine-daily-inquirer-1109/20160202/282428463217909

Gabinete, M. K. (2017). Semiotics in visual literacy pedagogy of junior high school teachers in the Philippines. https://www.researchgate.net/publication/317164773_Semiotics_in_Visual_Literacy_Pedagogy_of_Juni or_High_School_Teachers_in_the_Philippines

Gaines, E. (2001). Semiotic analysis of myth: A proposal for an applied methodology. http://www.wright.edu/ elliot.gaines/analysisofmyth.htm\#: :text=Myth\%20is\%20the\%20most\%20obvi ous, $1992 \% 2 \mathrm{C} \% 2039 \% 2 \mathrm{D} 42)$

Gaines, E. (2002). Semiotic analysis of myth: A proposal for an applied methodology. https://www.researchgate.net/publication/269789687_The_Semiotic_Analysis_of_Myth_A_Proposal_f or_an_Applied_Methodology

Giancarlo, A., Forsyth, J., Hiwi, B. T., \& McKee, T. (2021). Methodology and Indigenous memory: Using photographs to anchor critical reflections on Indian residential school experiences. Taylor and Francis Online. https://doi.org/10.1080/1472586X.2021.1878929

Goens, G. A. (2021). Getting the Message: The Wisdom of Listening and Thinking. Rowman \& Littlefield Publishers.

Grant, K. (2016). Denotation, connotation and myth. https://backspaceunwind.wordpress.com/2016/02/05/denotation-connotation-and-myth/

Guba, E. G., \& Lincoln, Y. S. (2005). Paradigmatic Controversies, Contradictions, and Emerging Confluences. In N. K. Denzin \& Y. S. Lincoln (Eds.). https://psycnet.apa.org/record/2005-07735-008

Guba, E. G., \& Lincoln, Y.S. (1985). Naturalistic Inquiry. Newbury Park, CA: Sage Publications.

Guedj, D. (2019). Double Tendance: The Photographic Message in the Egyptian Jewish Youth Magazine L'Illustration Juive, 1929-1931. https://brill.com/view/journals/ima/12/1/article-p56_5.xml

Halliday, M.K. (1978). The discourse studies reader: Main currents in theory and analysis. John Benjamins Publishing Company. shorturl.at/auEW0

Harahap, M.S., Kholil, S., \& Zulkarnain, I. (2020). Construction of Indonesian Muslim Identity in Photo News in National Newspaper in Medan City. Budapest International Research and Critics Institute-Journal. http://bircu-journal.com/index.php/birci/article/view/1288

Harrison, K. (2020). Visual literacy today. https://visualliteracytoday.org/about/

Hébert, L. (2006). Elements of semiotics. Signo. http://www.signosemio.com/elements-of-semiotics.asp

Hodge, R., \& Kress, G. (1988). Social Semiotics. Cambridge: Polity Press.

Huhtamo, E. (2003). Visual communication and semiotics: Some basic concepts. https://www.infoamerica.org/documentos_pdf/jacobson1.pdf

Ibrahim \& Sulaiman (2020). Semiotic Communication: An approach of understanding a meaning in 
communication. International Journal of Media and Communication Research, 1(1). https://journal.uir.ac.id/index.php/ijmcr/article/view/4584

Ingram, D., \& Henshall, P. (2019). Why do we need news pictures? The News Manual. https://www.thenewsmanual.net/Manuals Volume 2/volume2_46.htm

Jenkins, H. (2011). 'Transmedia 202: Further reflections'- Confessions of an aca-fan: The official weblog of Henry Jenkins. http://henryjenkins.org/2011/08/

Jewitt, C., \& Van Leeuwen, T. (Eds.). (2001). Handbook of visual analysis. London: Sage Publications.

Jhaveri, A. (2011). Rethinking journalism education through visual literacy. https://doi.org/10.13140/RG.2.1.4035.6883

Josephson, S. K., Kelly, J. D., \& Smith, K. (2020). Handbook of visual communication. Routledge. https://www.routledge.com/Handbook-of-Visual-Communication-Theory-Methods-and-Media/Josephs on-Kelly-Smith/p/book/9781138590311

Karunugan, R. (2019). The history of Philippine media. https://reneekarunungan.com/2020/02/19/the-history-of-philippine-media/

Kedra, J. (2016). Interpretation of journalistic photographs as an instrument of visual literacy education. Jyväskylä University Printing House. file:///C:/Users/User/Downloads/978-951-39-6796-3_vaitos10122016\%20(1).pdf

Kükürt, R. O. (2016). Semiology and a semiological reading of power myths in education. Educational Sciences: Theory and Practice. https://doi.org/10.12738/estp.2016.6.2105

Kuzu, S. T. (2016). The impact of a semiotic analysis theory-based writing activity on students' writing skills. Eurasian Journal of Educational Research, 63, 37-54. https://doi.org/10.14689/ejer.2016.63.3

Lacković, N. (2020). Thinking with Digital Images in the Post-Truth Era: A Method in Critical Media Literacy. Postdigit Sci Educ, 2, 442-462. https://doi.org/10.1007/s42438-019-00099-y

Lavalle, P. I., \& Briesmaster, M. (2017). The study of the use of picture descriptions in enhancing communication skills among the 8th-Grade Students-Learners of English as a Foreign Language. i.e.: inquiry in education, 9(1), Article 4. http://digitalcommons.nl.edu/ie/vol9/iss1/4

Leon, S. (2017). The semiotics of photography: Towards objective hermeneutics.

Lester, S. (1999). An introduction to phenomenological research. https://www.researchgate.net/publication/255647619_An_introduction_to_phenomenological_research

Li, J. (2008). Ethical Challenges in participant observation: A reflection on ethnographic fieldwork. The Qualitative Report, 13(1), 100-115.

Limesa, J. S. (2018). Denotative and connotative meanings in wonderfilled advertisement of Oreo. https://app.getpolarized.io/d/Denotative-Connotative-Meanings-Wonderfilled-Advertisement-Oreo/0x1 2S4ni7f2cZDezuhAGuV

Lovelace, A. (2010). Iconic photos of the Vietnam war and their influence on collective memory. https://vietnamiconicphotos.wordpress.com/tag/qualitative-analysis/

Lucman, S. T. (2020). Developing Social Justice Skills through Community Service-Learning in High School Social Studies. The Councilor: A Journal of the Social Studies, 81(2), Article 2.

Mambrol, N. (2016). Connotation and denotation. https://literariness.org/2016/03/18/connotation-and-denotation/

Mambrol, N. (2018). Structural linguistics. https://literariness.org/2018/12/22/structural-linguistics/

Matusiak, K.K., Heinbach, C., Harper, A. \& Bovee, M. (2019). Visual literacy in practice: Use of images in students' academic work. https://crl.acrl.org/index.php/crl/article/view/16950/19370

Mavrodieva, A.V. \& Shaw, R. (2021). Social media in disaster management. College and Research Libraries. https://www.ncbi.nlm.nih.gov/pmc/articles/PMC7972070/\#

McLeod, J. (2010). Case study research: In counselling and psychotheraphy. Sage Publications. from https://methods.sagepub.com/book/case-study-research-in-counselling-and-psychotherapy/n4.xml

Mendoza, R. U., Olfindo, R., \& Poco, L. (2017). Governance and Institutions in the Philippines. https://doi.org/10.2139/ssrn.2873942

Miles, M. B., \& Huberman, A. M. (1994). Qualitative data analysis: An expanded sourcebook (2nd ed.). Sage

54 Consortia Academia Publishing (A partner of Network of Professional Researchers and Educators) 
Looking at the bigger picture: A semiotic analysis on online news photographs

Publications. https://psycnet.apa.org/record/1995-97407-000

Mills, A. (2021). Word choice and connotation. Libretexts.

https://human.libretexts.org/Bookshelves/Composition/Advanced_Composition/Book\%3A_How_Argu ments_Work_-_A_Guide_to_Writing_and_Analyzing_Texts_in_College_(Mills)/08\%3A_How_Argum ents_Appeal_to_Emotion/8.02\%3A_Word_Choice_and_Connotation

Ming, F. \& Yan, S. (2014). Reinterpreting some key concepts in Brthes' theory. Academic Journals. https://pdfs.semanticscholar.org/3fdb/e79115db6f0f2162d3c10f3343f6f1b340e8.pdf

Mingers, J. \& Willcock, L.P. (2017). An integrative semiotic methodology for IS research. Science Direct. https://doi.org/10.1016/j.infoandorg.2016.12.001

Mirahmadizadeh, A., Ranjbar, K., Shahriarirad, R. Erfani, A., Ghaem, H., Jafari, K. \& Rahimi, T. (2020). Evaluation of students' attitude and emotions towards the sudden closure of schools during the COVID-19 pandemic: a cross-sectional study. https://doi.org/10.1186/s40359-020-00500-7

Miranda, J. O., \& Cruz, R. N. C. (2020). Resilience mediates the relationship between optimism and well-being among Filipino university students. https://doi.org/10.1007/s12144-020-00806-0

Miriam College (2020). HUMSS. https://www.mc.edu.ph/hs/humss

Mirzoeff, N. (1998). What is visual culture. Routledge. https://books.google.com.ph/books?hl=en\&lr=\&id=hhajBE0mUfwC\&oi=fnd\&pg=PR8\&dq=Mirzoeff, + N.+(1998).+What+is+visual+culture.\&ots=iw9xjZybk4\&sig=uuWan4Fn4MT3WvMctcFL9HALDjA \&redir_esc $=\mathrm{y} \# \mathrm{v}=$ onepage $\& \mathrm{q} \& \mathrm{f}=$ false

Mnyanda, L. (2017). Investigating the interplay between grade 9 learners' home visual literacy and their development of school visual literacy in English first additional language classrooms. South East Academic Libraries System. https://core.ac.uk/reader/145036944

Morabe, B. (2014). A semiotic analysis of President Benigno Aquino III's leadership images in selected Philippine Daily Inquirer photographs. Academia.

https://www.academia.edu/32058527/A_Semiotic_Analysis_of_President_Benigno_Aquino_IIIs_Leade rship_Images_in_Selected_Philippine_Daily_Inquirer_Photographs_Morabe

Mortelmans, D. (1998). Socio-semiotic analysis of print advertisements for luxury products. https://doi.org/10.1515/semi.1998.120.1-2.181

Mutangadura, J., Mann, C. C., \& Odendaal, L. (2019). Readers' and photojournalists' perceptions of print media road carnage images in The Herald. Taylor and Francis Online.

https://doi.org/10.1080/02500167.2019.1653343

Nassaji, H. (2015). Qualitative and descriptive research: Data type versus data analysis. Sage Publications. https://doi.org/10.1177/1362168815572747

National Commission for the Protection of Human Subjects of Biomedical and Behavioral Research (1979). The Belmont report: Ethical principles and guidelines for the protection of human subjects of research. https://www.hhs.gov/ohrp/regulations-and-policy/belmont-report/read-the-belmont-report/index.html

Navera, J. S., Garinto, L. B., \& Valdez, P. M. (2019). Teaching against the meme: Politics, argumentation and engagement in an ESL classroom in the Philippines.

https://search.proquest.com/docview/2265777307?pq-origsite=gscholar\&fromopenview=true

Neuman, W.L. (2014). Social research methods: Qualitative and Quantitative Approaches. Pearson Education Limited: United States of America

Newman, N. (2020). Executive Summary and Key Findings of the 2020 Report. http://www.digitalnewsreport.org/survey/2020/overview-key-findings-2020/

Nicomedes, C. J., Arpia, H. M., Roadel, R. M., Venus, C. A., Dela Vega, A.F., Ibuna, J. M., \& Avila, R. M. (2020). An evaluation on existential crisis of Filipinos during the Covid-19 pandemic crisis. https://doi.org/10.13140/RG.2.2.24958.61768

Nicomedes, C. J., Gamad, M. G., Dinglasa, J. R., \& Mañas, J. (2020). An Exploration of Filipino Resilience of Young Adults in the 21st Century. Research Gate. https://www.researchgate.net/publication/345757270_An_Exploration_of_Filipino_Resilience_of_Youn g_Adults_in the_21st_Century 
Moldez, C., \& Gomez, D.

Nilsson, M. (2017). Faster kind of photojournalism? Image-selection processes in a Swedish newsroom. Sciendo. https://doi.org/https://doi.org/10.1515/nor-2017-0413

Norman, D. (2013). The design of everyday things.

Nuzzaci, A. (2019). A picture is worth a thousand words: visual thinking between creative thinking and critical thinking in the teaching-learning processes. IMG Journal, 1(1), 234-253.

Oxford Dictionary. (2020). Online. https://www.lexico.com/definition/online

Palomares, P. P., Cadutdut, D. E., Amod, A. F., \& Tomaro, Q. P. V. (2021). Determining the motivations for political participation among elected youth leaders. Jurnal Study Pemerintahan. https://journal.umy.ac.id/index.php/jsp/article/view/10668

Park, M. (2015). Semiotic analysis of photojournalism captions: A comparison of Korean-English and Korean-Japanese translations. Taylor and Francis Online. https://doi.org/10.1080/0907676X.2015.1076491

Pastor, C. K. (2020). Sentiment analysis of Filipinos and effects of extreme community quarantine due to coronavirus (COVID-19) pandemic. SSRN. https://papers.ssrn.com/sol3/papers.cfm?abstract_id=3574385

Patton, M. Q. (2002). Qualitative research and evaluation methods. Sage Publications from https://us.sagepub.com/en-us/nam/qualitative-research-evaluation-methods/book232962

Punch, K. F. (1998) Introduction to social research: Quantitative and qualitative approaches. Semantic Scholar. https://pdfs.semanticscholar.org/102f/d15485e9facd6ed5c11633a6cab57e9ae667.pdf?_ga=2.108661643 $.804592520 .1596087069-1087264823.1596087069$

Rabbani, M., Pourrajab, M., \& Kasmaienezhadfard, S. (2015). Effects of pictures in textbooks on students' creativity. Multi Disciplinary Edu Global Quest, 4, 83-96. https://www.semanticscholar.org/paper/EFFECTS-OF-PICTURES-IN-TEXTBOOKS-ON-STUDENTS

Rao, V. C. (2017). A brief study of words used in denotation and connotation. Journal for Research Scholars and Professionals of English Language Teaching. http://www.jrspelt.com/wp-content/uploads/2017/07/Csrao-Denotations-n-Connotations.pdf

Reyes, M. C., Galdo, M. T., Mabandus, R. B., Mojica, T. M., \& Carvero, K. R. (2012). A semiotic analysis of five news stories in the Philippine Daily Inquirer and the Philippine Star. https://doi.org/10.7828/alcr.v1i1.176

Rice, C. (2016). 4 ideas from the photographic writings of Roland Barthes. https://www.bhphotovideo.com/explora/photography/tips-and-solutions/4-ideas-photographic-writings-r oland-barthes

Rifa, N. (2018). Roland Barthes' denotation, connotation, and myth in the change of four Starbucks logos: a study of semiotics. http://repository.unsada.ac.id/550/1/Chapter\%20I.pdf

Robinson, A. (2011). An A to Z of Theory Roland Barthes and Semiotics. Ceasefire. https://ceasefiremagazine.co.uk/in-theory-barthes-1/

Rodrigues, R.C. (2013). Photographic image: Thematization of its discourses. Scientific Research Publishing Inc. https://doi.org/10.4236/jsip.2013.44053

Romero, E. D., \& Bobkina, J. (2021). Exploring critical and visual literacy needs in digital learning environments: The use of memes in the EFL/ESL university classroom. Science Direct. https://doi.org/10.1016/j.tsc.2020.100783

Rotas, E., \& Cahapay, M. (2021). From stress to success: Exploring how Filipino students cope with remote learning amid COVID-19 pandemic. Journal of Pedagogical Sociology and Psychology. https://doi.org/10.33902/JPSP.2021366608

SAGE Publications. (2020). Semiotic analysis. https://us.sagepub.com/sites/default/files/upm-assets/106653_book_item_106653.pdf

Sagimin, E. M., \& Sari, R. (2020, April). A Semiotic Analysis on LAY's and EXO's Selected Music Videos. In Twelfth Conference on Applied Linguistics (CONAPLIN 2019) (pp. 43-50). Atlantis Press. https://www.researchgate.net/profile/Eka-Margianti/publication/340837939_A_Semiotic_Analysis_on LAY's_and_EXO's_Selected_Music_Videos/links/5ea5250145851553fab055de/A-Semiotic-Analysis-o

56 Consortia Academia Publishing (A partner of Network of Professional Researchers and Educators) 
Looking at the bigger picture: A semiotic analysis on online news photographs

n-LAYs-and-EXOs-Selected-Music-Videos.pdf

Saifuddin, F. (2018). Denotative and Connotative Meaning of Signs in Lombok Musical Instrument (Gendang

Beleq). International Journal of English Literature and Social Sciences.

https://doi.org/10.22161/ijels.3.1.17

Sanawi, J.B. (2014). Ideologies underlying the use of photographs in newspaper coverage of Bersih 3.0 rally: A social semiotic analysis. Malaysian Journal of Communication.

https://core.ac.uk/download/pdf/33344211.pdf

Semplici, S. (2015). Conflict of interest and professional ethics. Italian Journal of Pediatrics. https://doi.org/10.1186/1824-7288-41-S2-A65

Serafini, F. (2017). Visual literacy. Oxford University Press. https://doi.org/10.1093/acrefore/9780190264093.013.19

Shen, S., Cheng, C., Su, K., Zhang, X.m \& Zhang, T. (2021). A topic model-based framework for identifying the distribution of demand for relief supplies using social media data.

International Journal of Geographical Information Science.

https://doi.org/10.1080/13658816.2020.1869746

Shenton, A. K. (2004). Strategies for ensuring trustworthiness in qualitative research projects. Research Gate. https://www.researchgate.net/publication/228708239_Strategies_for_Ensuring_Trustworthiness_in_Qua litative_Research_Projects

Slobin, D. I. (2005). What is signifier and what is signified? Outside-in, Inside-out: Iconicity in Language and Literature, 4(4), 307.

Songcayaon, V., Legarde, M.A. \& Jungco, J.A. (2020). Children of the flood: The effect of flood on the psychological resilience of children. Asian Journal of Resilience.

https://www.asianjournalofresilience.com/index.php/ajr/article/view/9

Stahl, M. \& Kaihovirta, H. (2019). Exploring visual communication and competencies through interaction with images in social media. Science Direct. https://doi.org/10.1016/j.lcsi.2019.03.003

Stedman, K. (2019). To listen: Semiotics, deaf representation, and a silent voice. Senior Capstone Theses. https://scholarworks.arcadia.edu/cgi/viewcontent.cgi?article=1039\&context=senior_theses

Stewart, K. (2019). "Do you trust me(dia)?: How students perceive and identify fake news" Honors College Theses. 203. https://digitalcommons.pace.edu/honorscollege_theses/203

Streubert-Speziale, H.J. \& Carpenter, D.R. (2007) Qualitative research in nursing: Advancing the humanistic imperative. Lippincott Williams \& Wilkins, Philadelphia.

Sulistyo, E.T. \& Noh, L.M.M. (2020). Study on moral message pragmatic and aesthetic on the image for the young generation. International Journal of Art \& Design Universiti Teknologi MARA Cawangan Melaka. https://ir.uitm.edu.my/id/eprint/40847/1/40847.pdf

Tamble, M. (2019). 7 Tips for using visual content marketing. https://www.socialmediatoday.com/news/7-tips-for-using-visual-content-marketing/548660/

Tancinco, N.P. \& Concepcion, G.L. (2016). Social issues and concerns and their influences on the academic performance of social science students of Naval State University, Naval, Biliran, Philippines. International Journal of Sciences: Basic and Applied Research (IJSBAR).

Tee, M., Anlacan, J., Tee, A., Aligam, K., Reyes, P., Kuruchittham, V. \& Hog, R. (2020). Psychological impact of COVID-19 pandemic in the Philippines. Science Direct. https://doi.org/10.1016/j.jad.2020.08.043

Tester, B. (2017). Shifting focus: The role of visual literacy in the twenty-first century English classroom. https://digitalcommons.liberty.edu/masters/460/

The News Manual (2019). Chapter 46: News Pictures. https://www.thenewsmanual.net/Manuals\%20Volume\%202/volume2_46.htm

Thompson, D. S. (2018). Visual literacy, news literacy, and the fight against misinformation. Research Gate. https://www.researchgate.net/publication/329133909_Visual_literacy_news_literacy_and_the_fight_aga inst_misinformation

Tillman, A. (2012). What we see and why it matters: How competency in visual literacy can enhance student learning. Honors Projects. https://digitalcommons.iwu.edu/education_honproj/9/ 
Moldez, C., \& Gomez, D.

Topbas, S. (2011). War photography: A semiotic analysis of photographs in Turkish national press during the Cyprus operation in 1974.

https://openaccess.bilgi.edu.tr/bitstream/handle/11411/535/WAR\%20PHOTOGRAPHY\%20A\%20semi otic\%20analysis\%20of\%20photographs\%20in.pdf?sequence $=1$

Tovankasame, N., \& Labayo, C. (2021). Social responses and narrative experiences of the filipino middle class to the COVID-19 crisis. https://doi.org/10.47405/mjssh.v6i2.674

Treceñe, J. K., Matugas, A. M., Del Pilar, M. L., \& Palomar, M. D. (2019). "Dying in drugs": A photo elicitation technique on a maternal perspective towards the Philippine drug war. International Journal of Information Research and Review. https://www.ijirr.com/sites/default/files/issues-pdf/3306._0.pdf

Tria, J. Z. (2020). The COVID-19 pandemic through the lens of education in the Philippines: The new normal. International Journal of Pedagogical Development and Lifelong Learning, 1(1), 2-4. https://www.ijpdll.com/article/the-covid-19-pandemic-through-the-lens-of-education-in-the-philippinesthe-new-normal-8311

Trochim, W. M. K. (2020). Research methods knowledge base. https://tinyurl.com/y6b63qxk

Underwood, M. (2003). Introductory models and basic concepts: Semiotics. https://www.cs.princeton.edu/ chazelle/courses/BIB/semio1.html

Vaismoradi, M., Jones, J., Turunen, H., \& Snelgrove, S. (2015). Theme development in qualitative content analysis and thematic analysis. International Peer-reviewed and Open Access Journal for the Nursing Specialists. http://dx.doi.org/10.5430/jnep.v6n5p100

Vujović, M., \& Prelevic, S. (2014). Ethics of newspaper photography. http://casopisi.junis.ni.ac.rs/index.php/FUPhilSocPsyHist/article/view/511

Walsh, F. (2020). Loss and resilience in the time of COVID-19: Meaning making, hope, and transcendence. Wiley Online Library. https://doi.org/10.1111/famp.12588

Whedbee, K. E. (2008). In other's words: Plagiarism as deceptive communication. In R. L. Singh, K. S. Valde, \& K. E. Whedbee (Eds.), Ethics in human communication (6th ed., pp. 283-292). Long Grove, IL: Waveland.

Wong, V. S. (2019). Mapping the digital media publisher landscape in Philippines. https://hashmeta.com/blog/mapping-the-digital-media-publisher-landscape-in-philippines/

Writing Explained. (2020). What does the big picture mean? https://writingexplained.org/idiom-dictionary/the-big-picture\#: :text=The\%20Big\%20Picture $\% 20 \mathrm{Mean}$ ing,focus $\% 20$ on $\% 20$ the $\% 20$ small\%20details

Yan, S., \& Ming, F. (2015). Reinterpreting some key concepts in Barthes' theory. Academic Journals. http://academicjournals.org/journal/JMCS/article-abstract/ABC767050719

Yeung, J., \& Lenette, C. (2015). Stranded at sea: Photographic representations of the Rohingya in the 2015 bay of Bengal crisis. The Qualitative Report. https://nsuworks.nova.edu/tqr/vol23/iss6/3/

Yucel, H. (2019) Cultural identity in Turkish advertisements, Social Semiotics. Taylor and Francis Online. https://doi.org/10.1080/10350330.2019.1631463

Zuhdah, D. R., \& Alfain, S.N. (2020). An analysis of denotation and connotation in Chairil Anwar's poem. e-Journal of Linguistics. https://doi.org/10.24843/e-jl.2020.v14.i01.p11 